NBER WORKING PAPER SERIES

\title{
WHAT DO BUSINESS CLIMATE INDEXES TEACH US ABOUT STATE POLICY AND ECONOMIC GROWTH?
}

\author{
Jed Kolko \\ David Neumark \\ Marisol Cuellar Mejia \\ Working Paper 16968 \\ http://www.nber.org/papers/w16968
}

\author{
NATIONAL BUREAU OF ECONOMIC RESEARCH \\ 1050 Massachusetts Avenue \\ Cambridge, MA 02138 \\ April 2011
}

This paper previously circulated under the title "Public Policy, State Business Climates, and Economic Growth." Supported with funding from the David A. Coulter Family Foundation and the Donald Bren Foundation. We are grateful to McKinley Blackburn, Michael Dardia, Ellen Hanak, Debbie Reed, Robert Tannenwald, Michael Teitz, the editor, and anonymous reviewers for very thoughtful comments. Kolko and Neumark were affiliated with the Public Policy Institute of California (PPIC) when most of this research was conducted. Any views expressed are the authors' alone, and do not reflect the views of Trulia, PPIC, or the National Bureau of Economic Research.

NBER working papers are circulated for discussion and comment purposes. They have not been peerreviewed or been subject to the review by the NBER Board of Directors that accompanies official NBER publications.

(C) 2011 by Jed Kolko, David Neumark, and Marisol Cuellar Mejia. All rights reserved. Short sections of text, not to exceed two paragraphs, may be quoted without explicit permission provided that full credit, including $\odot$ notice, is given to the source. 
What Do Business Climate Indexes Teach Us About State Policy and Economic Growth?

Jed Kolko, David Neumark, and Marisol Cuellar Mejia

NBER Working Paper No. 16968

April 2011, Revised August 2012

JEL No. H2,H5,J21,O4

\begin{abstract}
$\underline{\text { ABSTRACT }}$
State business climate indexes capture state policies that might affect economic growth. State rankings in these indexes vary wildly, raising questions about what the indexes measure and which policies are important for growth. Indexes focused on productivity do not predict economic growth, while indexes emphasizing taxes and costs predict growth of employment, wages, and output. Analysis of sub-indexes of the tax-and-cost-related indexes point to two policy factors associated with faster growth: less spending on welfare and transfer payments; and more uniform and simpler corporate tax structures. But factors beyond the control of policy have a stronger relationship with economic growth.
\end{abstract}

Jed Kolko

Trulia

116 New Montgomery St, 3rd floor

San Francisco, CA 94105

jdkolko@yahoo.com

David Neumark

Department of Economics

University of California at Irvine

3151 Social Science Plaza

Irvine, CA 92697

and NBER

dneumark@uci.edu

\author{
Marisol Cuellar Mejia \\ Public Policy Institute of California \\ 500 Washington St., Suite 600 \\ San Francisco, CA 94111 \\ cuellar@ppic.org
}




\section{INTRODUCTION}

A fundamental goal of government policy is to encourage economic growth. States use a variety of strategies to encourage economic growth, such as job training, education, and infrastructure development, as well as low taxes and light regulation. At the same time, policies intended to protect workers, promote equity, improve the environment, and achieve other goals are sometimes seen as discouraging economic growth if they require taxes or regulations that impose costs on businesses or reduce peoples' incentives to work. These same taxes and regulations, though, might improve quality of life and make places more attractive to businesses and workers - ultimately even contributing to economic growth. The relationship, therefore, between any one policy and economic growth is complex.

The complexity multiplies when we consider all of the policies states use to encourage economic growth and all of the policies designed to achieve other goals, but which may also affect economic growth. Considering policies together, however, is necessary, because policies often work in combination rather than in isolation. For instance, taxes that increase the cost of doing business may also finance investments in transportation infrastructure - another policy - that helps businesses. While it is a matter for the political process to determine the right balance between encouraging economic growth and other goals, a crucial research question essential to informing policy debate over balancing economic growth and other goals is how state taxes, regulations, and other policies affect economic growth.

State business climate indexes summarize policies (and other factors) that might affect economic growth, and these indexes - published by many national organizations - often loom large in policy debate about economic growth. In this paper, we examine the relationships between a large set of state business climate indexes and state economic growth. We present detailed information on what the indexes capture, analyze whether they predict economic growth, and assess why particular indexes are or are not predictive of the economic outcomes we study, owing to the policies they capture or emphasize. We also broaden the analysis to consider other factors - such as weather ${ }^{1}$ and geography - that may affect economic growth and which, if ignored, may obscure the true relationship between the policies captured by business climate

\footnotetext{
1 "Weather" means time-specific atmospheric conditions, and "climate" means long-term atmospheric tendencies. Because we use the term "business climate" repeatedly and also include long-term meteorological climate measures as controls, to avoid confusion we the word "weather" rather than "climate" to refer to meteorological climate measures.
} 
indexes and economic growth.

The analysis focuses on state business climate indexes rather than the individual policy components that constitute them, for two reasons. First, because the indexes play a large role in policy debate, it is useful to understand their predictive power. More important, though, the indexes represent attempts to reduce to a single measure a large number of policy variables that could affect economic growth. Because the number of important policy components is large relative to the number of data points, some method of data reduction is essential. However, existing research has demonstrated that the estimated effects of individual policies are quite sensitive to the other policy variables included in models of economic growth (or other outcomes), in part because of high correlations among policies. Thus, the results from a model with limited policy variables could reflect either the effects of the included policies or the effects of the omitted policies. ${ }^{2}$

At the same time, we are of course interested in the effects of the policies the indexes capture, rather than the indexes themselves. If we focused only on business climate indexes, we would not identify the effects of individual policies. We therefore also focus more narrowly on better-defined subsets of policies by examining the "sub-indexes" of several indexes; each sub-index covers a narrower range of policies like regulatory measures, corporate income tax structure, or welfare and income-transfer policies. This analysis can provide more specific guidance in identifying policy factors that influence economic growth.

An important caveat should be noted at the outset. While we argue that there is merit in looking at bundles of policies via business climate indexes, this comes at a cost. In particular, some of the research strategies used to identify more rigorously the causal effects of a policy in studies focusing on a single policy are precluded. For example, it is difficult to think about how one would even propose an instrumental variable for a measure that aggregates many policies. And there is little variation over time, within states, in business climate indexes, ruling out state fixed-effects estimation. Nonetheless, we do what we can, given the constraints of the data, to assess and try to rule out non-causal interpretations of our findings. And we would argue that our evidence is at a minimum complementary to studies focusing on single policies, for which the

\footnotetext{
${ }^{2}$ There are numerous examples of research focusing on a limited or more extensive set of specific policies. Studies of policies in isolation have focused on taxes (e.g., Bartik, 1991; Buss, 2001; Papke, 1991; Carlton, 1983) and regulation (e.g., Holmes, 1998); for reviews see Wasylenko (1997), Buss (2001), and Tannenwald (1997). Studies focusing on a fairly limited set of policies include Wasylenko and McGuire (1985), Bartik (1985), and Helms (1985). In contrast, Crain and Lee (1999) and Reed (2009) employ long lists of candidate variables to explain state economic growth, finding that the results are sensitive to model specification, but also identifying a subset of robust variables.
} 
gain from more rigorous identification must be offset against the likely confounding of effects of multiple policies. $^{3}$

Finally, factors affecting economic growth might vary at the local, regional, or state level. For example, within a state, metropolitan areas can have different patterns of economic growth, industrial composition, and workforce characteristics, as well as different local policies. ${ }^{4}$ Despite the economic variation within states - especially large ones - we focus on business climate indexes and policy at the state level. Although state boundaries do not necessarily reflect labor or product markets or have any other inherent economic meaning, states set important economic policies, and the tendency of business climate indexes to rank states rather than metropolitan areas or other regions reflects the expected importance of taxes, regulations, investments, and other policies set at the state level. Also, even though metropolitan areas within states can have different industrial compositions and different economic growth patterns, economic growth rates for states overall clearly differ, with some states growing faster than others, often persistently. There is, therefore, plenty of variation in economic growth rates between states to explain, and many of the most likely policy factors that affect these economic growth rates are determined at the state level.

\section{POLICY DEBATE AND THE CONTRADICTORY NATURE OF STATE BUSINESS CLIMATE}

\section{RANKINGS}

In policy debate, the question of how government policies affect economic growth is often couched in terms of the "business climate," especially at the state level, and there is a cottage industry of state business climate indexes that fuels this debate. These business climate indexes figure prominently in policy debate, perhaps most commonly in arguments for lowering taxes and regulations in states that do poorly on indexes that emphasize these costs of doing business and taxes more generally. Conversely, states that do well on such indexes - because of low taxes, for example - often tout these indexes or rankings in trying to attract businesses (Kolko et al., 2011). Not surprisingly, politicians and other organizations use state rankings provided by business climate indexes to support their point of view. They are often able to do this selectively

\footnotetext{
${ }^{3}$ Parent and LeSage (forthcoming) discuss a similar problem of an extensive list of possible influences - policy and other factors - in the context of explaining regional patterns of innovation.

${ }^{4}$ Indeed there are attempts to rank metro areas' business climates, either using wage and rent premia, as in Gabriel and Rosenthal (2004) and Albouy (2009), or business climate rankings of metropolitan areas that parallel the state indexes (Beacon Hill Institute, 2007). However, emphasizing the point that policies are set more at the state level, the latter rankings rely heavily on state policy prevailing in the metropolitan area of interest.
} 
because state business climate rankings can provide strongly divergent views of state policy environments. For example, some states that are ranked poorly in terms of taxes are ranked favorably on other dimensions, such as education and human capital, or quality of life measures including crime rates and health. ${ }^{5}$

Such conflicting information from state business climate indexes provides part of the motivation for this study. More generally, though, we study how state policy environments, as captured by state business climate indexes, predict state economic growth, both to inform our understanding of these indexes, and to help identify which policies are more important determinants of state economic growth. To do this, we collected data and detailed information on 11 well-known business climate indexes. We included indexes that have published rankings for multiple years and made their methods transparent, including providing a full list of the components that constitute the index. For several indexes, we also collected data and information on their sub-indexes, which we explain below.

The first column of Table 1 lists the indexes included in our study and the institution that creates the index (as well as the years covered). ${ }^{6}$ For reasons discussed later, we label these PROD1-PROD5, TXCST1TXCST5, and FISCPOL. The next two columns describe the focus of each index, and list the categories of policy variables covered by each index (out of 14 that we have created based on the content of the indexes). It is clear that the indexes aim to capture different facets of the policy environment. Thus, it would not be surprising if states are ranked differently depending on the business climate index, and if the indexes varied in the extent to which they predict economic growth. In addition, the institutions that create these indexes sometimes have specific agendas that may influence what policies they emphasize, which might or might not be the factors most predictive of economic growth. ${ }^{7}$

\footnotetext{
${ }^{5}$ To clarify the language we use below, a higher value of an index implies a better rating of the business climate - so that the ranking is closer to one.

${ }^{6}$ We also examined the American Legislative Exchange Council (ALEC)-Laffer State Economic Competitiveness Index, the California Economic Performance Card, created by the California Foundation for Commerce and Education, and Best States for Business created by Forbes Magazine. However, the first is available only for 2008 and 2009, the second only for 2008, and the third only from 2006 through 2009, hardly overlapping our sample period. In addition, there is not sufficient detail available for Forbes' Best States for Business, making it impossible to evaluate how the index was generated in terms of variables, sources, weights, and aggregation methods.

${ }^{7}$ For example, the Economic Freedom Index (TXCST4) is created by the Pacific Research Institute, whose mission is to "champion freedom, opportunity, and personal responsibility for all individuals by advancing free-market policy solutions." (See http://liberty.pacificresearch.org/about/default.asp, viewed November 4, 2009). In contrast, the Corporation for Enterprise Development, which constructs three of the indexes we study (Table 1), describes itself as "[d]riven to create a more robust, fair and sustainable economy for all of us, ... fueled by the belief that there is a
} 
Table 2 shows how the 50 states rank on the business climate indexes. We first average each index's ranking across the years for which the index is available. Then in the second and third columns we report the average of these averages for the first five indexes (PROD1-PROD5) and the next five (TXCST1-TXCST5); as we discuss later, these sets of indexes naturally group together. In the last two columns, we report the minimum and maximum for the state across average rankings of the different individual indexes. The table reveals that states' positions in the rankings can vary wildly from one index to another. Indeed, the smallest difference between the minimum and maximum average ranking for states is 21 , and for 16 states the range is 40 or higher. In fact, across all 50 states, every state but one (Hawaii) ranks in the top 20 in at least one index, and every state ranks in the bottom half in at least one index. Thus, based on these indexes, nearly every state could be praised for having a good business climate, or criticized for having a bad one.

\section{PAST RESEARCH ON BUSINESS CLIMATE INDEXES AND OTHER DETERMINANTS OF}

\section{GROWTH}

\section{Assessments of Business Climate Indexes ${ }^{8}$}

Erickson (1987) reviews the development of business climate indexes in the United States, ascribing the beginning of modern business climate indexes to: the 1975 Fantus company index, prepared for the Illinois Manufacturers' Association; the Alexander Grant \& company (later, Grant Thornton) index, first prepared for the Conference of State Manufacturers' Associations in 1979; and the Inc. magazine Report Card on the States, first published in 1981. Two early academic studies assess the relationship between these early indexes and economic outcomes (Plaut and Pluta, 1983; and Skoro, 1988). A later paper (Holmes, 1998) suggested that the Fantus index captures an important pro- or anti-business stance of state policy. Including this index accounted for a positive relationship between right-to-work laws and manufacturing employment, also highlighting the problem that conclusions about a given state policy can be misleading without taking account of the many other state policies that can be reflected in a business climate index.

A second and larger wave of business climate indexes - including many of the indexes we consider

tremendous amount of untapped potential in low-income people and distressed communities." (See http://www.cfed.org/focus.m, viewed November 4, 2009).

${ }^{8} \mathrm{We}$ focus on studies of business climate indexes and how well they predict state economic growth. There is a larger literature on state (and MSA) economic growth and convergence; a recent example is Bauer et al. (forthcoming). 
in this paper - is assessed in more recent work. Fisher (2005) provides a sweeping critique of five business climate indexes. He is particularly critical of the "arbitrary" weighting of components in the construction of most indexes, in contrast to regression models that assign weights based on predictions of economic performance. Fisher also highlights the sensitivity of business climate indexes to specification and variable definition, criticizes the inclusion in indexes of variables that should be viewed as outcomes, and flags the potential for reverse causality with policy responding to growth rather than the other way around.

There are problems with Fisher's assessment of these business climate indexes, which we improve upon in a number of ways. First, he restricts tests of predictive power to simple correlations or regressions in which the only control other than the index is a lagged level of the dependent variable. Because many factors could be correlated with business climate indexes as well as economic performance, his tests are prone to omitted variable bias. Second, Fisher assesses indexes on their own terms - such as analyzing how well the tax-focused State Business Tax Climate index corresponds with other tax measures - rather than comparing the predictive power of multiple indexes for economic performance measures of interest, like growth in output, employment, or income. At the same time, we address some of the problems that he highlighted, including robustness of the evidence, the inclusion of outcomes in the indexes, and reverse causality.

Bittlingmayer et al. (2005) use a more uniform framework that facilitates comparisons across indexes and attempts to control for other factors. Rather than including controls for other state-level variables that could affect economic growth, they study pairs of counties that straddle state borders, estimating relationships between the county ratios of business climate indexes and outcome growth rates. Their evidence is mixed, but it suggests that for some indexes a better business climate ranking predicts positive economic outcomes. Foreshadowing our results to some extent, they find that indexes more narrowly focused on tax policies are more likely to have positive relationships with growth than are broader measures, but also that the indexes with these positive relationships explain little of the variation in economic growth.

This study also has potentially serious limitations. First, it uses a good deal of data on outcomes two to three decades prior to the business climate measures. Second, border areas can sometimes be poorly representative of entire states. Coastal states - where a disproportionate share of U.S. economic activity is located - tend to have their economic and population centers on the coast since oceans and lakes facilitate 
trade and transportation. In states with smaller coastlines, like New York or Pennsylvania, economic centers might be both on the coast and near state borders; but in states with larger coastlines, like California and Florida, the vast majority of economic activity is far from state borders, and border areas of those states are economically distinct from the rest of the state. Third, economic activity in border areas is probably more sensitive to differences in state tax and regulatory policies since both sides of the border share similar economic conditions and may be in the same labor market. Thus, it is preferable to assess state business climate indexes using state-level data.

Finally, Garrett and Rhine (2010) assess the relationship between state employment growth and the Economic Freedom Index of North America index and its sub-indexes. This index and its "size of government" sub-index has a positive and statistically significant (10-percent level) relationship with employment growth in the periods 1980-1990, 1990-2000, and 2000-2005; the relationship for the "labor market freedom" sub-index is significant for the latter two periods and of larger magnitude than for the size of government sub-index. Similar to the approach we take, they regress growth rates on the initial values of the index, controlling for density, industry mix, and other factors. However, they consider only the one index, and in their analysis of sub-indexes they report only regressions on each separately, despite high positive correlations among the sub-indexes (documented later).

Recent work on regional economic differences estimates the relative productivity of metropolitan areas, rather than states, using weighted averages of residuals from wage and rent equations, following the Roback (1982) model of spatial equilibrium (Gabriel and Rosenthal, 2004; Albouy, 2009). This method does not require selecting or identifying factors that might enhance productivity, which offers the advantage of avoiding the arbitrary weighting schemes in business climate indexes, although of course it is more reliant on economic theory. Nonetheless, this approach parallels the use of business climate indexes, in that it studies a measure that aggregates across many policies to try to characterize the policy environment and economic conditions facing businesses in different areas. It does not distinguish, however, between policies and other factors that affect productivity.

\section{Factors Beyond Policy}

Factors beyond the immediate or even longer-term control of state and local policymakers likely 
affect economic growth as well, and if we do not account for these factors, then estimated relationships between business climate indexes - and the policies underlying them - and economic outcomes can be misleading. For example, the local and regional growth literature emphasizes persistent - and sometimes quite immutable - characteristics like the local industry mix (Glaeser et al., 1992; Henderson et al., 1995). In the short or medium term, policymakers probably can do little to change the industry composition of their region, even if investments in education or infrastructure might, over the long-term, help shift a local economy from one set of industries to another. This literature has also emphasized that mild weather and other amenities can contribute to local quality of life (Glaeser et al., 2001), leading workers to accept lower wages to live and work in more appealing places, so businesses not tied to specific locations for other reasons can lower their labor costs by locating in places with positive amenities. Geographic features like coastal proximity can also matter (Rappaport and Sachs, 2003); historically, proximity to waterways facilitated trade of manufactured goods, though as the U.S. economy has become more service-based this advantage of coastal locations (or location next to natural resources) has diminished. Population density can affect growth in either direction - enhancing growth through the beneficial effects of the proximity of other businesses, workers, and knowledge (“agglomeration economies"), or slowing growth owing to congestion and higher land costs.

\section{DATA}

\section{Economic Outcomes}

We focus on growth in employment, total wages, and Gross State Product (GSP). Job growth is at the center of policy debate, but policymakers also care about earnings, ${ }^{9}$ perhaps in part because higher wages generate higher tax revenue and reduce other government expenditures. GSP and wages are related, but GSP is broader: it is measured as the sum of wages (equivalently, labor income), capital income (returns to business owners, corporations, and other owners of capital), and business taxes. Finally, we measure job growth at new businesses, responding to a general and long-standing policy focus on the importance of small businesses (which new businesses always are) in job creation (Neumark et al., 2011).

\footnotetext{
${ }^{9}$ A state's policies might be judged as more successful if they create high-wage jobs. The evidence points to the same types of policies increasing employment growth and wage growth (when they have an effect), suggesting that employment gains are coming in jobs paying wages that are roughly the same, on average, as the existing stock of jobs.
} 
We use the Quarterly Census of Employment and Wages (QCEW) to measure overall employment growth through 2008. The QCEW also gives a measure of total compensation paid during a calendar quarter to covered workers, which we aggregate to measure annual wage growth. ${ }^{10}$ The GSP data (in current dollars) come from the Bureau of Economic Analysis. GSP is derived as the sum of the GDP originating in all the industries in a state. Given that there is a discontinuity in the GSP time series in 1997, with the change from SIC to NAICS industry definitions, we use GSP growth for 1997-2008. We use the National Establishment Time-Series (NETS) to measure employment growth at new businesses. ${ }^{11}$ We had NETS data through 2006.

\section{Business Climate Indexes}

We collected data on 11 business climate indexes for all available years from 1992 through $2008 .^{12}$ For each of the 11 indexes we use the index values rather than the ranking, which allows us to capture information on the magnitudes of the gap between states, which tend to be larger for states nearer to the tails of the distributions of the indexes. Because index definitions can change from year to year, we standardize each index for each year, subtracting off its mean and dividing by its standard deviation. The indexes are signed such that positive values correspond to what is intended to reflect a "better" business climate, based on the intention of the creators of each index (e.g., low taxes). In some cases, we used the underlying data to construct modified forms of the indexes, described below.

\section{Business climate sub-indexes}

Several of the business climate indexes also define and report scores for sub-indexes; these subindexes aggregate up to the "parent" index, so when we substitute the full set of sub-indexes for the corresponding index, we do not omit other policies included in the index (although the weighting of specific policies is fixed). We discuss the content of these sub-indexes later.

\section{Control Variables}

\footnotetext{
${ }^{10}$ The wage measure includes total compensation paid during the calendar quarter, regardless of when services were performed, and includes pay for vacation and other paid leave, bonuses, stock options, tips, the cash value of meals and lodging, and in some states, contributions to deferred compensation plans (such as 401(k) plans).

${ }^{11}$ We also estimated the models for employment growth using the NETS, to verify that the results are similar. The present paper reports employment results only for the QCEW data. Results with the NETS, and additional information on the NETS data, are provided in Kolko et al. (2011).

${ }^{12}$ Our sample period ends in 2008 but the dependent variables for the last year are measured as changes to 2008, so in our regressions we use indexes through 2007. However, some of the tables showing descriptive information on the indexes refer to the latest year for which an index was available.
} 
We included other control variables common in the urban and regional literature, except that we are purposely not using as controls other variables that the literature often includes in growth regressions - like educational attainment - that are included in business climate indexes (since they reflect policy). Because the business-climate indexes span so many different variables, this leaves a relatively small set of additional controls, mainly focused on amenities or other geographic or long-standing economic factors that could influence economic growth.

First, we use weather variables from Mendelsohn et al. (1994), capturing both temperature and precipitation. These were originally calculated at the county level; we use county-population-weighted state averages based on 2006 Census population estimates. We define "Mild" as the negative of the absolute value of the difference between monthly average temperature and 20 degrees Celsius, summed over January, April, July, and October, and "Dry" as the negative of the average monthly precipitation for those four months, in centimeters. ${ }^{13}$ Second, we use "Proximity," defined as the negative of the average distance from the state's county centroids, weighted by county population, to the nearest coast, Great Lake, or major river (Rappaport and Sachs, 2003). With the multiplication by -1 , higher values of these measures reflect milder weather, drier weather, and closer proximity to navigable water. Third, we define population density as the tractweighted population density across the state (and use this in natural logarithms), based on 1990 Census data (Glaeser and Kahn, 2004). ${ }^{14}$

Finally, we construct a measure of the state-specific "shift-share" or "industry composition effect" attributable to the baseline industry mix of the state and national growth by industry, to account for variation

\footnotetext{
${ }^{13}$ We experimented with more flexible specifications of the weather variables. First, to allow more flexible effects of weather, we estimated specifications adding quadratic terms in the mild and dry weather variables. Second, to allow deviations from mild temperature to be asymmetric in the hot and cold directions, we broke the temperature variable into two components: one measuring deviations from 20 degrees Celsius in the summer, and one in the winter. The estimated relationships of our growth measures with the business climate indexes for our main specifications (Tables 6 and 7, discussed below) were very similar.

${ }^{14}$ Even though population density is measured prior to our sample period, it could be endogenously related to government policy that evolves slowly over time. One reason to include population density as a control is to capture how possible it is for places to grow, and population density seems the best variable to capture this. High-density metropolitan areas have higher land prices and lower elasticity of housing supply. Thus, if we tried instead to capture limitations on growth in dense places with land prices, the endogeneity bias would be more severe; the lower elasticity implies that an outward shift in demand for locations in high-density places will raise price more than quantity relative to demand shifts in lower-density places. The relative population density of areas changes much more slowly over time and is less likely to reflect these demand shifts. Nonetheless, we have estimated our main specifications (Tables 6 and 7) excluding density, and the results were again very similar.
} 
in state economic growth due to the mix of industries in each state. For example, California's strong economic growth during the high-tech boom of the late 1990's could have occurred because high-tech expanded more in California than it did in other states, or California could have exhibited strong economic growth during the high-tech boom simply because high-tech grew strongly everywhere, and high-tech was originally over-represented in the state. The industry composition effect variable controls for the second type of influence, which seems less likely to have anything to do with state policy.

We start with the industry composition of employment in each state in 1992 (our base year), and calculate how employment would have grown had employment in each industry in the state grown at the average rate of growth of the industry's employment in the other 49 states. This calculation is done at the level of 3-digit NAICS industries. Letting EIS denote the industry composition effect, $E$ denote employment, the subscripts $i$ and $j$ denote states, and the subscript $k$ denote industry, this variable is defined as:

$$
E I S_{i}=\frac{\left\{\sum_{k} E_{i k, 1992} \cdot\left[\frac{\sum_{j \neq i} E_{j k, 2006}-\sum_{j \neq i} E_{j k, 1992}}{\sum_{j \neq i} E_{j k, 1992}}+1\right]\right\}-E_{i, 1992}}{E_{i, 1992}} \cdot 100
$$

\section{Descriptive Information on State Economic Growth and Controls}

Descriptive statistics on the growth and control variables are reported in Table 3. Of perhaps greatest interest is employment growth, which averages 1.6 percent annually by state (unweighted). The rates of growth of GSP and total wages are higher because they are measured in current dollars (nominal growth is removed in the regressions by including year dummy variables). The rate of employment growth due to births is also higher, because this measure does not capture employment reductions due to deaths (or employment changes due to expansions, contractions, or relocation into or out of states).

\section{WHAT DO THE BUSINESS CLIMATE INDEXES CAPTURE?}

The eleven indexes arrive at such contradictory rankings of business climates across states because different indexes include or emphasize different factors. Table 4 shows this by grouping our 14 policy categories into three broad classes: taxes and costs; productivity (and quality of life); and other. We then show the weights that each index puts on the 14 categories as well as the broad class. This table highlights sharp differences in the policies that indexes emphasize. For example, the indexes we labeled TXCST1TXCST5 (as well as FISCPOL) focus heavily on taxes, costs, and regulation and litigation. The PROD2 
index emphasizes quality of life and equity measures, and the PROD1 emphasizes human capital, new businesses, and technology. More generally, all five of the indexes labeled PROD capture elements of what we consider productivity of the workforce or quality of life factors; hence the label. The table reveals differences within these groups - such as the sole emphasis of the TXCST1 index on taxes, the emphasis of the TXCST4 and TXCST2 indexes on regulation and litigation, and the inclusion of welfare and transfer payments in the TXCST4 and TXCST5 indexes. ${ }^{15}$

Table 5 shows the correlations of the indexes, averaged over time, across states. Among the PROD1PROD5 indexes, the correlations are positive and generally large. On the other hand, the correlations of these five indexes with the next set of five (TXCST1-TXCST5) are mostly negative, and in many cases (especially when they are not negative) quite small. Conversely, the correlations among the latter fives indexes are uniformly positive, and again quite large. The correlations of the FISCPOL index with the other ten indexes, shown in the last row, are generally small and vary in sign, which is why we use a separate label for this index. To assess more systematically the impressions given by these correlations, we performed a variety of cluster analyses on the average index values, finding that there were two distinct clusters - one that generally included the first five indexes listed above, and one that generally included the second set of five indexes. The last index (FISCPOL) was more or less randomly assigned to one cluster or the other.

The correlations and cluster analysis suggest that there are two distinct clusters of indexes. The first includes the PROD1, PROD2, PROD3, PROD4, and PROD5 indexes. Tables 1 and 4 showed that these indexes reflect productivity of the workforce and other quality of life measures; we hence categorize these indexes as belonging to the "productivity" cluster. ${ }^{16}$ The second distinct cluster includes the TXCST1, TXCST2, TXCST3, TXCST4, and TXCST5 indexes, and based on what these indexes cover, we categorize

\footnotetext{
${ }^{15} \mathrm{We}$ also constructed a much more detailed list of the variables within each of our 14 categories that go into each index (available from the authors upon request). This, too, is informative for interpreting the indexes. For example, the TXCST1 index weighs a broad range of tax rates, while others (the PROD5 and TXCST3 indexes) try to summarize all of this information in a single tax burden, and yet others (such as the FISCPOL index) emphasize a small set of taxes. Similarly, the list reveals the kinds of variables used to capture quality of life (such as crime rates and infant mortality) and equity (such as the poverty rate, and inequality in the income distribution).

${ }^{16}$ From the perspective of urban economics, the predicted effects of factors that affect productivity and factors that affect quality of life are different. But these predictions are for wage levels (positive in the first case, and negative in the second), not for wage growth or the other dimensions of growth we study. Moreover the spirit of our study is not to construct new indexes, but to take them as given. In practice, the indexes do combine these two factors. But the table of correlations (Table 5) combined with the table of weights (Table 4) makes clear that even though the "productivity" indexes weight different things differently as between quality of life and productivity, the correlations are very high.
} 
this as the "tax-and-cost" cluster." ${ }^{, 17}$ We did not assign FISCPOL to either cluster. ${ }^{18}$ This analysis of the content of the indexes, and the identification of two main clusters that underlie most of them, helps explain the contradictory state rankings across the various indexes (as well as why we label the first five indexes similarly and the next five similarly). Given the broad similarities of how states are ranked within the taxand-cost and productivity clusters, but the lack of relationship between how states are ranked across these two clusters, we focus on comparing these two clusters in analyzing the relationship between business climate indexes and economic growth.

\section{EMPIRICAL ANALYSIS OF BUSINESS CLIMATE INDEXES AND STATE ECONOMIC GROWTH:}

\section{METHODS}

We estimate state-level regressions, over time, for growth in four measures: QCEW employment; QCEW wages; GSP; and NETS employment due to births. Given that the business climate indexes are typically available only for a subset of years (see Table 1), and that there is often not much overlap between the years available for different indexes, for the most part we study one index at a time for the years for which that index is available. Because inter-temporal correlations of the indexes are generally very high, exceeding 0.7 or 0.8 even for observations eight or nine years apart, we would be unlikely to get very different answers if we had the index values for other years.

Our specifications define the index or sub-index at time $t$, and growth from $t$ to $t+1$. We also explored the sensitivity of the results to varying the length of the interval over which growth is measured, and shifting this interval relative to measurement of the business climate index. All specifications include year fixed effects to capture the aggregate business cycle, so that we identify the effects of the policies captured by state business climate rankings on how state growth differs from the aggregate.

It is natural to think about estimating these regression models with state-specific fixed effects, to try to identify the effects of changes in the policies captured by a state's business climate index while avoiding

\footnotetext{
${ }^{17}$ Note that we group "welfare and transfer payments" with taxes and costs even though we treat equity outcomes as contributing to quality of life. Net of the income distribution, higher welfare and transfer payments implies more redistribution via taxes. The latter implies more deadweight loss from taxation, and more importantly more work disincentives, which can clearly lower the level of economic activity. Likely reflecting this argument, Table 4 shows that the indexes emphasizing taxes and costs are the ones that put any weight on welfare and transfer payments.

${ }^{18}$ FISCPOL also puts weight on taxes, but with lots of weight on a measure of size of government that makes this index quite independent of the other five indexes in the "tax-and-cost" cluster.
} 
the confounding influence of time-invariant state characteristics that affect economic growth. However, the high inter-temporal correlations within nearly all of the indexes imply that there is little to be learned from regression models with fixed state effects. ${ }^{19}$ Consequently, our regression models primarily identify the effects of variation in the policies captured in business climate indexes and sub-indexes from cross-state variation, and rather than including fixed state effects, we incorporate the controls for state characteristics likely to affect economic growth that were described earlier. Finally, we report some results with dummy variables for the four Census regions.

Letting $\Delta Y_{i t}$ denote the growth measures for state $i$ in year $t, B C_{i t}$ denote the index, $X_{i}$ denote the control variables, and $D_{t}$ denote the year fixed effects, we estimate regression models of the form:

$$
\Delta Y_{i t}=\alpha+\beta B C_{i t}+X_{i} \delta+\sum_{t} \theta D_{t}+\varepsilon_{i t}
$$

As usual, there are questions of the endogeneity of policy, because policies may be affected by economic activity, especially when looking at outcomes and policies at the same jurisdictional level. We do not believe there are compelling instrumental variables to solve this problem, though others have tried to predict changes in specific policies using political-cycle events like term-end behavior (Besley and Case, 1995) or determinants of political influence related to an area's political representatives (Hanson and Rohlin, 2010). The problem is particularly difficult because $B C$ captures a number (and often a very large number) of policies. One could think about using economic development policies in neighboring states, but given the possibility of inter-jurisdictional competition (e.g., Brueckner, 2003) the exogeneity of neighboring states' policies is questionable. Thus, we are limited to addressing this issue by carefully controlling for underlying trends at the state level, through the industry composition effect variable, and through some other analyses specific to particular variables or hypotheses of interest that are discussed later. We also suspect that any endogeneity problems are less severe when we study the aggregate business climate indexes, in contrast to the narrower sub-indexes; in the former case, the large number and types of policies captured in the indexes makes it less likely that state economic growth drives the measured policy variation.

\footnotetext{
${ }^{19}$ Moreover, within-state variation in the indexes over time may reflect a good deal of measurement error, given the numerous subjective and somewhat ad hoc decisions that go into constructing the indexes, as well as actual errors in measurement. With this type of measurement error, controlling for fixed state effects likely biases the estimated effects of the indexes toward zero, and could result in more biased estimates than cross-sectional regressions without fixed effects.
} 
An ideal analysis of the empirical content of business climate indexes might estimate relationships between business climate indexes and economic growth over a long sample period in the past, and then test the ability of business climate indexes to forecast economic growth out of sample. However, given the relatively short sample period available to us, this is infeasible.

\section{EMPIRICAL ANALYSIS OF BUSINESS CLIMATE INDEXES AND STATE ECONOMIC GROWTH: RESULTS}

\section{State Economic Growth and Business Climate Indexes}

Tables 6-8 report the estimates of Equation (2) for the different economic growth measures. A set of regressions for each business climate index is reported. In each case, we first estimate the model with nothing but the business climate index and year fixed effects as independent variables, defining the dependent variable as the one-year percentage change. We then augment this model with the controls for the industry composition effect, population density, weather, and proximity to navigable water, and then add the Census region dummy variables. We also estimated these specifications for annualized percent changes computed over two- and three-year periods, to establish that the qualitative findings are robust. ${ }^{20}$

Table 6 reports results for employment growth as measured by the QCEW. In Table 6, for all of the productivity indexes, as well as FISCPOL, the estimated relationship between the index and QCEW employment growth is either small and not statistically significant, with a central tendency of about zero, or anomalously negative and significant (for PROD4). The estimated coefficients of the tax-and-cost indexes are all positive, and strongly significant for TXCST1 and TXCST5. The indexes are standardized, so the coefficients reflect the estimated effect of a one-standard deviation increase in the index. We also report, in square brackets, the change in the growth rate of employment associated with a move in the rankings from the $40^{\text {th }}$ to the $10^{\text {th }}$ state - a substantial "jump up" in the rankings - based on the average values of the index for the included years.

The strongest and most robust evidence is for the TXCST1 and TXCST5 indexes: we find positive, sizable, and statistically significant estimates for every specification we estimated. Taking the estimate from

\footnotetext{
${ }^{20}$ These and many other findings we discuss but do not report in the tables are available in Kolko et al. (2011), or from the authors upon request.
} 
the second panel of Table 6 of 0.20 for the TXCST5 index implies that moving a state from the $40^{\text {th }}$ to the $10^{\text {th }}$ place in the rankings would increase the rate of growth of employment by 0.36 percentage point $-\mathrm{a}$ substantial increase compared with the mean employment growth rate of 1.61 percent reported in Table 3.

The bottom specification reports the estimates when we add the Census region dummy variables along with the other controls. In this case, the evidence becomes stronger, with positive and significant estimates for all five of the tax-and-cost business climate indexes. (The evidence from these specifications is also strong for wage growth, as reported below.) In our view, it is not obvious that we should rely only on the evidence from the specifications with Census region dummy variables included. Variation across regions may be as important as or more important than variation within regions. For example, evidence on migration patterns suggests that states do not compete only with bordering states or states within the same region. ${ }^{21}$ Clearly, though, if the reader believes that the effects are better identified within regions, then more weight should be put on these latter specifications, which only strengthen our findings.

The table divides the results for the different "clusters" of indexes discussed earlier; to reiterate, the first five constitute the productivity cluster, and the next five the tax-and-cost cluster. All of the indexes for which there is evidence of a positive relationship between the index and employment growth are in the taxand-cost cluster. Conversely, none of the indexes in the productivity cluster has a positive relationship with employment growth. Thus, the principal result that emerges is that states with policies that lead them to be ranked better on the tax-and-cost-focused indexes - meaning lower taxes, lower regulatory costs, etc. - have faster employment growth.

The results for the control variables are similar for the specification shown in the table and the others we estimated but do not report (with, for example, longer windows for estimating growth rates). We refer to the specification reported in the second panel as our "baseline" specification. The estimated coefficients of the industry composition variable are more or less centered on one. Population density is almost always negatively associated with employment growth, and the estimate is generally statistically significant. This

\footnotetext{
${ }^{21}$ For a convenient look at migration flows, see http://www.forbes.com/2010/06/04/migration-moving-wealthyinteractive-counties-map.html?preload=48453 (viewed February 13, 2012). See also evidence from the ACS reported in “Are the Rich Leaving California?" http://www.ppic.org/content/pubs/jtf/JTF_LeavingCAJTF.pdf (viewed February 13, 2012).
} 
presumably reflects the higher growth rate associated with a lower base, more room to expand, lower land costs, and so on, offsetting any agglomeration effects. The "dry" variable is always estimated to be positively associated with employment growth, although the estimate is not statistically significant. In contrast, there is a strong positive association between mild weather and employment growth. Somewhat surprisingly, perhaps, the estimated effect of proximity to navigable water is negative, and sometimes statistically significant. This is not the usual predicted effect from models of economic geography, but may reflect shifts in recent decades towards services and low weight-to-value products that have made proximity to water less important. (These results for the other controls are very similar for the regressions for the other dependent variables, and hence are not reported in the following tables.)

Table 7 reports estimates for wage and GSP growth. The findings are similar to those for employment growth, though somewhat less strong. None of the productivity indexes has a positive, statistically significant relationship with either outcome when we include controls. In contrast, with controls included the TXCST5 index has a persistent positive and significant estimated effect on these two outcomes. Although not reported in the table, as in the employment growth regressions, mild weather, the industry composition effect, and lower population density are positively associated with wage and GSP growth.

Finally, Table 8 reports results for employment change due to establishment births. In contrast to the previous results, the policies captured in the productivity indexes predict employment change due to births at least as strongly as the tax-and-cost indexes, when controls are included. Four of five of the productivity indexes (PROD1, PROD2, PROD3, and PROD4) have a positive, statistically significant relationship (at the 10-percent level) with employment change due to births; several of the tax-and-cost indexes do as well, and the TXCST4 coefficients are larger than those of the productivity indexes or the other tax-and-cost indexes. Nonetheless, we emphasize our results on overall growth in employment, wages, and GSP. It is unclear whether greater employment growth due to births in the absence of greater net employment growth is advantageous; a larger role for births could lead to higher long-term economic growth if new firms take advantage of newer technologies and processes that allow them to generate longer-term growth. ${ }^{22}$ However,

\footnotetext{
${ }^{22}$ If the productivity indexes are associated with employment change due to births but not with overall employment change, they must also be positively associated with gross job destruction. We confirmed that most of the productivity
} 
dividing our years into two time periods and regressing later growth on both earlier and later values of the indexes revealed no evidence that the policy variables captured in the productivity indexes are associated with future growth. But given that the index rankings are generally quite stable over time, it is hard to separate contemporaneous from lagged effects of policies captured in the indexes, and the absence of long time-series makes it difficult to test propositions about longer-term growth.

We carried out several sensitivity tests or additional analyses to assess the validity of the results.

First, because indexes in the productivity cluster include components that we consider to be outcomes, rather than policy factors that affect outcomes, we recalculated these indexes and generate modified indexes stripped of outcome components. ${ }^{23}$ Our regression results changed little with these modified indexes, which is perhaps not surprising since the indexes in the productivity cluster generally showed no positive relationships with growth in net employment, wages, or GSP in the first place.

Second, we repeated the regressions for the tax-and-cost cluster adding a control for the PROD4 index, the only index from the productivity cluster that generally has a statistically significant (albeit negative) relationship with growth in the regression models with the control variables included. Although we know from Table 5 that indexes in different clusters have no statistically significant positive correlations, some pairs - like TXCST3 and PROD4 - exhibit significant and large negative correlations, raising the possibility that we are misattributing the effects of the policies in an index to those in another cluster when we include each index singly in Tables 6-8. The tax-and-cost cluster index coefficients changed very little when the PROD4 index was included as a control.

Third, we re-ran our baseline models with some additional controls from just prior to the sample period - the share of the population with a high-school degree or more (from the 1990 Census), the share of the state's U.S. House delegation in 1991 that was Democratic, and the Democratic share of the presidential vote in the state in 1992. The first captures baseline skill or education differences, and the latter two capture political ideology that may shape policy. We did not include these controls in our core models because they

indexes are positively associated with components of gross job creation and gross job destruction, which could imply that the productivity indexes are associated with the "creative destruction" emphasized by Schumpeter (1942).

${ }^{23}$ Examples are: the employment growth measures, unemployment rate, involuntary part-time employment, and pay measures in the PROD2 index; and initial public offerings and "gazelle" jobs in the PROD1 index. We were able to generate the PROD1 and the three DRCS indexes (PROD2-PROD4) omitting the outcome components. 
may to some extent reflect policy, and hence over-control for the policies captured in the business climate indexes. Nonetheless, the results were robust to the inclusion of these controls. Interestingly, as well, the Democratic vote share was consistently associated with lower growth of all of our measures, and the relationship was nearly always statistically significant for employment and GSP growth.

Fourth, we re-ran our baseline models including state fixed effects. As expected from the high correlation of business climate indexes for states over time, standard errors increased considerably, and almost no coefficients of the indexes were statistically significant. More specifically, for the tax-and-cost indexes, the coefficient estimates were often little changed, but the standard errors were so much larger that these estimated coefficients were no longer statistically significant. We therefore interpret these fixed-effects results as providing no additional insight while at the same time not contradicting our main results.

Fifth, as noted earlier, it is possible that industry mix is partly a function of policy, given the persistence over time of the business climate indexes. If so, it is possible that we are over-controlling for policy by including the industry composition control. We therefore estimated the baseline specification omitting the industry control. The estimates were largely unchanged. There was, though, a hint of evidence consistent with the over-controlling concern, as the estimated relationships between some of the tax-and-cost indexes and employment growth in a couple of instances (wage and GSP growth, for the TXCST2 index) became stronger positive and statistically significant. However, the qualitative conclusions are the same, and it is not clear that one wants to give credit to the policies captured in the business climate indexes if industry composition is actually driving things exogenously.

Sixth, a potential concern is that the tax-and-cost indexes do not isolate the effects of taxes, because the specifications with these indexes may not adequately control for expenditures. This concern is not strongly justified, for a number of reasons. First, some of the tax-and-cost indexes have information on government expenditures; this is discussed in more detail below with respect to the TXCST4 and TXCST5 indexes. Second, as we also discuss below, it appears to be tax complexity (especially with regard to corporate taxes) that matters, rather than the level of marginal rates, yet there is no reason to expect complexity to be correlated with expenditures. Nonetheless, given that the PROD2 and PROD3 indexes include some categories related to government expenditures, we re-estimated the models for the tax-and-cost 
indexes including these other two indexes as controls. The estimates are often not directly comparable to what is reported in Tables 6-8, because the PROD2 and PROD3 indexes are not always available for the same years. Nonetheless, the estimates were generally unchanged qualitatively. For the TXCST1 regressions, these two productivity indexes are available for the same years, and the estimates were virtually unchanged.

Seventh, one concern in interpreting the evidence relating the policies captured in the tax-and-cost indexes to growth is that the causality could go the other way, with growth leading to lower taxes subsequently (and hence a higher ranking). To assess this, we estimated regressions asking whether the policies captured by the indexes respond to earlier growth. For each index, we divided the years available (as closely as possible into half) into "early" and "late" years. We then estimated regressions of the average values of the index for the late years, in each state, on the average values for the early years, and QCEW employment growth (annualized) over those same early years. If the policies captured by the indexes are endogenous, we might expect positive coefficients on early growth for the indexes, with earlier growth leading to lower taxes in the future. There was, in fact, no clear pattern in the data, with positive and negative estimates for the tax-and-cost indexes; there were three positive and two negative estimates, and of these, one of the positive and one of the negative estimates were significant. Therefore, there is no indication that high rankings on the tax-and-cost indexes are explained by earlier strong growth - the endogeneity story of most concern in interpreting our results.

Finally, one might be interested in growth in per capita wages or GSP, rather than growth in levels. In our view - which guided our analysis - policymakers focus on growth per se. Consider the emphasis in the media and national policy discussion on GDP growth, and the broader concerns of increasing versus decreasing population or sizes of economies (across countries). Nonetheless, we also estimated these per capita growth regressions. The results are consistent with what one would expect from the results reported above, when changes in employment are driven principally by changes in population, rather than changes in employment-to-population ratios. Specifically, the taxes-and-cost indexes have roughly equal relationships with employment growth on the one hand, and wage growth and GSP growth, on the other, and hence essentially no predicted relationship with growth in per capita wages or per capita GSP. In addition, because the policies captured by the productivity indexes are either not associated with wage and GSP growth or 
negatively associated, and are not associated with employment growth, we get negative associations with per capita wage and GSP growth. Thus, nothing in these results points to any more evidence of positive effects of the policies captured in the productivity indexes, and the evidence indicates that the policies captured by the tax-and-cost indexes predict growth in the size of economies, rather than per capita output or wages. ${ }^{24}$

We explored two possibilities for heterogeneous effects. First, we added an interaction between the business climate index and the national value for the dependent variable to our baseline regressions with controls in Tables 6-8. We also split our sample based on years when national GDP growth was above or below median annual national growth for the sample period and repeated our baseline regressions for each sub-period. The relationship between the policies captured by the business climate indexes and economic growth did not vary with national economic growth. Second, we explored whether the relationship between the business climate indexes and economic growth was similar in states with a good deal of economic activity near a state border, like New Hampshire or Maryland, and in states with most economic activity far from state borders, like California or Texas. To do this, we included an interaction between the share of workers that commute daily across state lines in either direction (based on 1990 Census data) and the business climate index (as well as the main effect of this cross-commuting measure) in our baseline regressions with controls in Tables 6-8. There was no evidence that state economic growth is more sensitive to the business climate in states where many businesses are near another state's border.

Our last extension was to look at whether economic growth in more "footloose" industries - based on industry differences in rates of gross job creation and destruction due to relocation (Kolko and Neumark, 2007) - is more sensitive to differences in state business climates. Industries that serve a national or international market should be more geographically mobile than those tied to local markets (such as services delivered in person, like haircuts, or retailers) or dependent on local natural resources or features (like mining, forestry, or shipping). The most footloose sectors are manufacturing (NAICS 31-33), information (51), finance and insurance (52), and professional and technical services (54). We re-estimate the regression

\footnotetext{
${ }^{24}$ Results from estimates of wage premia at the state level, following Albouy (2009), parallel this conclusion. These premia are negatively correlated with the tax-and-cost indexes, and positively correlated with the productivity indexes. Given that the tax-and-cost indexes are positively associated with economic growth, and assuming that production amenities dominate wage premia, the implication is that factors that affect productivity levels (raising wages) differ from factors that affect growth. Urban economic theory does not predict that production amenities are tied to growth rates.
} 
models for manufacturing only and for information, finance and insurance, and professional and technical services together. We look separately at manufacturing because, unlike the other three sectors, it has long had a declining share of employment, has traditionally provided reasonably high-paying jobs for middle-class workers, and is often the target of specific tax credits and economic development efforts. We look at private sector employment and wages in these industries, from the QCEW.

The results are reported in Table 9. For both employment and wages, the relationship between business climate indexes in the tax-and-cost cluster and growth is stronger for manufacturing than for overall employment. The top panel of Table 9 shows that the estimated coefficients on three indexes - TXCST1, TXCST2, and TXCST3 - are at least twice as large for manufacturing (second row) as for overall privatesector employment (first row), and the TXCST2 and TXCST3 coefficients become statistically significant for manufacturing. Comparing overall private-sector employment with the three footloose nonmanufacturing sectors (third row), no clear pattern emerges: coefficient magnitudes are similar, and two of the five indexes are statistically significant for footloose employment and overall private sector employment, compared with four for manufacturing employment. The results for wage growth in the bottom panel of Table 9 are broadly similar. Finally, looking at the estimated effect of the policies captured by the productivity indexes on these same sectors, there is still no consistent relationship with economic growth, with the exception of PROD1. The stronger predictive power that PROD1 has for QCEW employment and, even more so, for wages may be due to the overlap between PROD1's heavy emphasis on indicators relevant for technology and related industries and our definition of "footloose industries," which includes the information sector and other technology industries. These PROD1 results highlight that business climate measures geared toward specific industries may predict growth in those industries better than they predict growth for the economy overall.

\section{The Business Climate versus Other Factors}

The previous results showed that the policies captured in the tax-and-cost indexes have positive relationships with economic growth, though factors beyond policy also contribute strongly (as reported in Table 6). To compare the estimated contributions to state economic growth of the policy and non-policy factors, for each index we calculate the estimated contribution of the business climate index to QCEW 
employment growth, $\hat{\beta}\left(B C_{i}-\overline{B C}\right)$, and the estimated total contribution of the five non-policy factors to employment growth, $\left(X_{i}-\bar{X}\right) \hat{\delta}$, where $\hat{\beta}$ and $\hat{\delta}$ are the estimates from Table $6 ; i$ indexes states. We average these estimates over the models for the three indexes with fairly consistent relationships with economic growth (TXCST1, TXCST4, and TXCST5), yielding two measures for each state: the estimated contribution of the business climate to employment growth; and the estimated contribution of the five non-policy factors.

Figure 1, which plots the estimates, shows that there is less variation in employment growth associated with the business climate indexes than with the other factors. The implication is that the business climate (as captured by the indexes) helps determine economic growth, but it is not as important as the combined effect of the other factors, although it is most amenable to policy change.

The figure also highlights differences across groups of states regarding the business climate and nonpolicy factors. Mountain states like New Mexico, Nevada, and Arizona have the most favorable set of nonpolicy factors; this region tends to have milder, drier weather, and lower population density. Rhode Island, Connecticut, and Indiana have the least favorable set of non-policy factors. The business climate makes the most negative estimated contribution to employment growth in New York, California, and Rhode Island. In contrast, the business climate makes the most positive contribution in Nevada, Wyoming, and South Dakota, and in two of these three states the other factors are also advantageous.

Many states have both a favorable business climate and favorable non-policy factors, such as Nevada, Colorado, Arizona, Wyoming, and Texas, while other states are unfavorable on both dimensions, like New York, Rhode Island, and New Jersey. For both sets of states, ignoring non-policy factors could lead to giving the business climate undue credit (or blame) for high (or low) employment growth since the nonpolicy factors contribute to employment growth in the same direction as the business climate does. In a few states, the business climate and non-policy factors have offsetting estimated effects on employment growth. Although harder to see in the figure, Indiana, Tennessee, and several other mostly southern states have favorable business climates yet unfavorable non-policy factors. A more striking outlier is California, which has one of the least favorable business climates, but is in the top tier of states based on non-policy factors.

\section{BUSINESS CLIMATE SUB-INDEXES: WHICH TAXES AND COSTS MATTER?}

To dig beneath the indexes while still avoiding the insurmountable problem of using individual 
policy variables, we use sub-indexes that exist for three of the tax-and-cost indexes - TXCST1, TXCST4, and TXCST5. ${ }^{25}$ These sub-indexes are explained in Table 10. Fortunately, this list includes the two indexes with the strongest positive relationship with economic growth (TXCST1 and TXCST5). Each of TXCST1's sub-indexes focuses on a particular type of taxation, while the sub-indexes of TXCST4 and TXCST5 also cover the level and composition of government spending, regulatory and judicial factors, and other costs of doing business. Because the sub-indexes capture narrower, more clearly defined sets of policies than the overall indexes, the relationship with economic growth may be stronger for some individual sub-indexes than for the parent indexes.

The TXCST5 and TXCST4 sub-indexes require some deciphering with respect to measuring size of government versus welfare and transfer payments. Only one of the three variables in TXCST5's size of government sub-index - "general consumption expenditures by government as percentage of GDP" - falls under what we classify as size of government. The other two variables in the TXCST5 size of government sub-index - transfers and subsidies as a percent of GDP, and social security payments as a percent of GDP fall into our "welfare and transfer payments" category. Thus, the TXCST5 size of government sub-index, despite its name, consists mostly of measures reflecting the extent of spending on welfare, social security, ${ }^{26}$ and transfer payments, and hence is most similar to TXCST4's welfare spending sub-index; both consist primarily of components in the welfare and transfer payments category.

The TXCST1 corporate tax sub-index also requires clarification. It is comprised of two groups of variables. The first group includes measures of the corporate tax rate structure, which includes the top marginal tax rate but also the number of tax brackets and their threshold levels; a lower top rate and a flatter rate structure contribute to a better sub-index score. The second group includes measures of the corporate tax base; more generous net-operating-loss deductions and fewer corporate tax credits are two of the measures

\footnotetext{
${ }^{25}$ We focus only on the tax-and-cost cluster in our analysis of sub-indexes, based on the previous evidence that only the indexes in this cluster predict economic growth. We were also able to examine evidence for sub-indexes that were available on a consistent basis over time for four of the productivity indexes (PROD1-PROD4). Paralleling the results for the "parent" indexes, none of the sub-indexes within the productivity cluster had a consistent, significant positive relationship with economic growth.

${ }^{26}$ This is not the usual meaning of "social security," but instead refers more generally to unemployment insurance, disability insurance, workers compensation, and public pensions, defined at the state level. We believe the specific data item to which this refers is the state government "Insurance Trust Expenditure" category in the Census Bureau's government finance statistics (http://www.census.gov/govs/www/06classificationmanual/chapter05.html\#p2c534, viewed July 19, 2010).
} 
that contribute to a better sub-index score. Net-operating-loss deductions, in effect, tax firms on their average profitability over time, which the TXCST1 index considers desirable. Tax credits complicate the tax system and narrow the tax base, which the TXCST1 index considers undesirable.

Estimates of the same regressions as before, but substituting the sub-indexes for the corresponding parent index, are reported in Table 11. We present results for the baseline specification; results were similar for the other variants of the specifications in Tables 6-8. Among the five sub-indexes of TXCST1, the corporate income tax sub-index has a positive and statistically significant relationship at the 5-percent level with both wage growth and GSP growth. ${ }^{27}$ We explored whether this apparent effect of corporate taxes stems from variation in marginal rates or other aspects of the tax code, by replacing the corporate tax sub-index with the top marginal rate. The latter variable had no statistically significant relationship with any of our economic growth measures. Moreover, when we included both the top marginal corporate tax rate and the corporate tax sub-index in the model, the tax rate had no relationship with any growth outcome, and the estimated coefficient of the corporate tax sub-index remained of similar magnitude and significance. Thus, the positive relationship we observe between the sub-index and growth does not appear to be driven by the top marginal tax rate, but rather by other factors such as the simplicity of corporate taxation and its uniformity with federal taxation.

Among the TXCST5 sub-indexes, the size of government sub-index stands out as having a positive and significant relationship at the 1-percent level with employment and wage growth. And among the TXCST4 sub-indexes, one - welfare spending - stands out; this sub-index has a statistically significant relationship at the 10-percent level or less with all growth measures except wage growth, and the largest coefficient estimate among the TXCST4 sub-indexes for all growth measures. ${ }^{28}$ Note that the TXCST4 and

\footnotetext{
${ }^{27}$ We subjected the TXCST1 sub-indexes to an additional robustness test. Because TXCST1 only includes components for tax rates and tax burdens, the TXCST1 sub-index model tells us about tax base composition, which could be correlated with expenditure composition and therefore subject to omitted variable bias since the TXCST5 and TXCST4 results (discussed later) suggest that expenditure composition matter for economic growth. We re-ran the model with all TXCST1 sub-indexes (Table 11) and added the TXCST5 size of government sub-index (which is available for many of the same years); this resulted in little or no change in the coefficient estimates or significance on the TXCST1 corporate tax sub-index.

${ }^{28}$ As a sensitivity check for the tax-and-cost sub-index results, we re-estimated these specifications including (separately) each of the five productivity indexes, for years for which the productivity index was also available. This analysis allows for the possibility that the productivity index is an omitted variable correlated with tax-and-cost subindexes and an economic growth measure. For only one combination of a sub-index (the TXCST4 welfare spending
} 
TXCST5 sub-indexes that stand out comprise similar policy measures; TXCST5's size of government subindex and TXCST4's welfare spending sub-index both consist primarily of variables describing government expenditures on welfare and transfer payments. Because the TXCST5 and TXCST4 indexes have subindexes covering many types of taxes and other costs businesses face - including regulation, policies affecting labor costs, and more - our finding that the composition of government expenditure matters for economic growth is based on an analysis that controls for a wide range of other taxes and costs. These subindex results are, in general, stronger and more robust than the results for the business climate indexes overall.

The sub-index analysis yields two main conclusions. First, among taxes, the corporate income tax structure and base matter for wage and GSP growth, though not necessarily for employment growth. Only the TXCST1 index has sub-indexes that distinguish different tax streams, so this finding comes entirely from that one index. Second, greater government expenditure on welfare and transfer payments is associated with slower economic growth. The strength of this second conclusion is reinforced by its consistency across two different business climate indexes, covering different years and different sub-indexes that serve as controls in our model. Admittedly, the TXCST5 size of government sub-index contains more than conventional welfare and transfer spending. But the TXCST4 welfare spending sub-index focuses only on the latter, and the results for the TXCST4 welfare spending sub-index are qualitatively similar (and in some ways stronger, and in particular predictive of GSP growth) than the results for the TXCST5 size of government sub-index.

At the same time, there are some reasons for caution regarding the findings for welfare and transfer payments. One is that there may be reverse causality, with welfare and transfer payments rising when economic growth is slower (as more people become eligible for payments or for higher payments). Because the TXCST5 size of government sub-index defines these payments as a share of GSP (rather than relative to population, as in the TXCST4 welfare spending sub-index), the possibility of this type of bias is even stronger for this sub-index, as slow GSP growth can also feed directly into a higher share of payments 
relative to GSP. This suggests that if there is reverse causality, we should find a stronger positive relationship with the welfare and transfer payment sub-index (a high value of the sub-index implies low payments) and economic growth for the TXCST5 size of government sub-index, and in particular for the GSP growth results for that sub-index. It turns out that we can rule out this "mechanical" type of endogeneity bias stemming from the inclusion of GSP in the denominator of the TXCST5 size of government sub-index. First, we also find significant estimated effects in this direction for the TXCST4 welfare spending sub-index. Most important, perhaps, we find a significant relationship between GSP growth and the TXCST4 welfare spending sub-index but not the TXCST5 size of government sub-index, the opposite prediction from what we would expect if reverse causality from defining payments as a share of GSP were driving the results.

Another reason to be less concerned about reverse causality is that we use across-state rather than within-state variation to identify the effects of the policies captured by the business climate indexes. Endogeneity bias is likely reduced by avoiding reliance on short-term changes in state economic conditions that could affect some of the policy variables. Indeed, when we simply ran regressions paralleling those in Table 11 using the state averages (i.e., the between regression), the results were similar, although sometimes a little weaker.

A second reason for caution about the findings for welfare and transfer payments is that the TXCST5 size of government sub-index includes a broader set of expenditures, including state retirement pensions. The sub-index could therefore be high when a state has a large retirement population (for example, Florida), and this could be associated with lower economic growth, but not because these payments change behavior and lower growth. However, this concern is assuaged by the fact that the results are similar for the TXCST4 welfare spending sub-index, which includes only state expenditures focused much more sharply on the "welfare" population. In addition, the large retiree population in a state like Florida consists of many migrants from other states, so the retirees would not likely be a source of high state retirement pension expenditures.

Overall, these considerations make us more confident - but not definitive - in interpreting the combined evidence as identifying the effects of welfare and transfer spending on economic growth. At a minimum, however, the evidence from the tax-and-cost-related business climate indexes implies that 
concerns that high taxes and costs of doing business slow state economic growth need to be taken seriously. And this applies particularly to corporate taxation and welfare and transfer payments, identified by the analysis of the tax-and-cost sub-indexes as the potentially most important policies related to taxes and costs of doing business.

\section{CONCLUSIONS AND DISCUSSION}

Business climate indexes that emphasize taxes and costs predict economic growth, especially for the manufacturing sector. Indexes that focus on productivity measures do not predict growth in employment, wages, or GSP - only in births. Although factors beyond the control of state policy, such as the industry mix and weather, generally have a stronger relationship with economic growth than do the tax-and-cost policies captured by business climate indexes, tax-and-cost-related policies are more amenable to change.

The tax-and-cost indexes span many policy areas. Looking at the sub-indexes of three business climate indexes focused on taxes and costs identified a subset of individual sub-indexes that predict many economic growth measures better than their parent indexes do. For one tax-and-cost index (TXCST1), the sub-indexes cover different types of taxes, and only the corporate income tax sub-index predicts higher growth. Corporate tax features other than the top marginal rate are responsible for this sub-index's positive relationship with economic growth. This evidence is plausible from an economic perspective, as factors that contribute to a worse ranking on the corporate tax sub-index - like a plethora of corporate tax credits, and greater complexity of the tax structure more generally - increase costs of compliance and create economic distortions that could impede growth.

The sub-indexes of two of the other tax-and-cost indexes (TXCST5 and TXCST4) span more areas of taxes and costs. The sub-indexes that focus on taxation had no significant relationship with economic growth. However, two sub-indexes focused on welfare and transfer payments exhibit a robust relationship indicating that lower welfare and transfer payments are associated with faster economic growth. Why might lower welfare and transfer payments contribute to higher economic growth? Any program whose benefits or eligibility depends on low income or non-employment status provides some disincentive to work or to work less if employed. Welfare reforms attempted to encourage work in a number of ways, including job search requirements, limited years of eligibility, and less steep reductions in welfare payments with increases in 
earnings. Despite these changes, welfare-type programs and transfer payments - by their nature - still tend to create work disincentives (just not as strong as they were in the past).

It is important to emphasize that our analysis focuses on economic growth. Other policies that could adversely affect economic growth - including welfare and transfer payments - might contribute to other goals like equity. Nonetheless, over the longer run strong economic growth is a prerequisite for generating the economic resources needed to pursue goals other than growth. In that sense, our findings confirm and emphasize the equity-efficiency tradeoff with respect to state-level public policy and economic growth.

Finally, in addition to asking what the business climate indexes tell us about policy, we have also learned something about the potential value of these business climate indexes in policy debate. We noted that the organizations that create these indexes often have political agendas, and that the indexes are used selectively in policy debate. Our results indicate that the indexes capturing taxes and other costs of doing business seem to capture something meaningful about state business climates, insofar as the outcome of interest is economic growth, whereas those capturing elements of productivity and quality of life do not. Of course we have not attempted to construct our own index. It is possible that the productivity indexes contain a more heterogeneous set of factors, and this obscures underlying relationships between economic growth and some of the policies they capture. However, that argument is at least partially undermined by the failure to find sub-indexes of the productivity indexes that predict economic growth. An alternative, which we cannot rule out based on our analysis, is that the policies underlying the productivity indexes contribute to other desirable features of state economies - or states more generally - that are not related to economic growth. More evidence along these lines might provide a better rationale for the importance of the productivity indexes in policy debate about state economic performance. 


\section{References}

Albouy, David. 2009. "What are Cities Worth? Land Rents, Local Productivity, and the Capitalization of Amenity Values," Cambridge, MA: NBER Working Paper \# 14981.

Bartik, Timothy J. 1985. "Business Location Decisions in the United States: Estimates of the Effects of Unionization, Taxes, and Other Characteristics of States," Journal of Business \& Economic Statistics, 3, 14-22.

Bartik, Timothy J. 1991. "Who Benefits from State and Local Economic Development Policies?" Kalamazoo, MI: W.E. Upjohn Institute for Employment Research.

Bauer, Paul W., Mark E. Schweitzer and Scott Shane. Forthcoming. "Knowledge Matters: The Long-Run Determinants of State Income Growth," Journal of Regional Science.

Beacon Hill Institute. "Metro Area Competitiveness Report 2007," Suffolk University, Boston, MA, available at http://www.beaconhill.org/compete07/compete2007MetroBHI.pdf (viewed January 31, 2012).

Besley, Timothy and Anne Case. 1995. "Does Electoral Accountability Affect Economic Policy Choices? Evidence from Gubernatorial Term Limits," Quarterly Journal of Economics, 110, 769-798.

Bittlingmayer, George, Liesl Eathington and Arthur P. Hall. 2005. "Business Climate Indexes: Which Work, Which Don't, and What Can They Say About the Kansas Economy?” Topeka, KS: Kansas, Inc., Research Report.

Brueckner, Jan. 2003. "Strategic Interaction Among Governments: An Overview of Empirical Studies," International Regional Science Review, 26, 175-188.

Buss, Terry F. 2001. "The Effect of State Tax Incentives on Economic Growth and Firm Location Decisions: An Overview of the Literature," Economic Development Quarterly, 15, 90-105.

Carlton, Dennis W. 1983. "The Location and Employment Choices of New Firms: An Econometric Model with Discrete and Continuous Endogenous Variables," Review of Economics and Statistics, 65, 440-449.

Crain, W. Mark and Katherine J. Lee. 1999. "Economic Growth Regressions for the American States: A Sensitivity Analysis," Economic Inquiry, 37, 242-257.

Erickson, Rodney A. 1987. "Business Climate Studies: A Critical Evaluation," Economic Development Quarterly, 1, 62-71.

Fisher, Peter. 2005. Grading Places, Washington, DC: Economic Policy Institute.

Gabriel, Stuart A. and Stuart S. Rosenthal. 2004. "Quality of the Business Environment Versus Quality of Life: Do Firms and Households Like the Same Cities?" Review of Economics and Statistics, 86, 438-444.

Garrett, Thomas and Russell Rhine. 2010. "Economic Freedom and Employment Growth in U.S. States," St. Louis, MO: Federal Reserve Bank of St. Louis Working Paper 2010-006A.

Glaeser, Edward, Hedi D. Kallal, Jose A. Scheinkman and Andrei Shleifer. 1992. "Growth in Cities," Journal of Political Economy, 100, 1126-1152.

Glaeser, Edward L. and Matthew E. Kahn. 2004. "Sprawl and Urban Growth," in J.V. Henderson and J.F. Thisse (eds.), Handbook of Regional and Urban Economics, Vol. 4. Amsterdam: Elsevier B.V, 2004, pp. 2482-2527.

Glaeser, Edward, Jed Kolko and Albert Saiz. 2001. “Consumer City,” Journal of Economic Geography, 1, 27-50.

Hanson, Andrew and Shawn Rohlin. 2010. "Do Location-based Tax Incentives Attract New Business Establishments?" Journal of Regional Science, 51, 427-449.

Helms, L. Jay. 1985. "The Effect of State and Local Taxes on Economic Growth: A Time Series - Cross Section Approach," Review of Economics and Statistics, 67, 574-582.

Holmes, Thomas. 1998. "The Effect of State Policies on the Location of Manufacturing: Evidence from State Borders," Journal of Political Economy, 106, 667-705.

Kolko, Jed and David Neumark. 2007. Business Location Decisions and Employment Dynamics in 
California. San Francisco, CA: Public Policy Institute of California.

Kolko, Jed, David Neumark and Marisol Cuellar Mejia. 2011. "Public Policy, State Business Climates, and Economic Growth," Cambridge, MA: NBER Working Paper No. 16968.

Mendelsohn, Robert, William D. Nordhaus and Daigee Shaw. 1994. "The Impact of Global Warming on Agriculture: A Ricardian Analysis," American Economic Review, 84, 753-771.

Neumark, David, Brandon Wall and Junfu Zhang. 2011. "Do Small Businesses Create More Jobs? New Evidence for the United States from the National Establishment Time Series," Review of Economics and Statistics, 93, 16-29.

Papke, Leslie E. 1991. “Interstate Business Tax Differentials and New Firm Location,” Journal of Public Economics, 45, 47-68.

Parent, Olivier and James P. LeSage. Forthcoming. "Determinants of Knowledge Production and their Effects on Regional Economic Growth," Journal of Regional Science.

Plaut, Thomas and Joseph Pluta. 1983. "Business Climate, Taxes and Expenditures, and State Industrial Growth in the United States," Southern Economic Journal, 50, 99-119.

Rappaport, Jordan and Jeffrey Sachs. 2003. "The United States as a Coastal Nation," Journal of Economic Growth, 8, 5-46.

Reed, W. Robert. 2009. "The Determinants of U.S. State Economic Growth: A Less Extreme Bounds Analysis," Economic Inquiry, 47, 685-700.

Roback, Jennifer. 1982. “Wages, Rents, and Quality of Life,” Journal of Political Economy, 90, 1257-1278.

Schumpeter, Joseph. 1942. Capitalism, Socialism, and Democracy. Harper: New York (republished in 1975).

Skoro, Charles. 1988. "Rankings of State Business Climates: An Evaluation of Their Usefulness in Forecasting," Economic Development Quarterly, 2, 138-152.

Tannenwald, Robert. 1997. "State Regulatory Policy and Economic Development," New England Economic Review, March/April, 83-99.

Wasylenko, Michael. 1997. "Taxation and Economic Development: The State of the Economic Literature," New England Economic Review, March/April, 37-52.

Wasylenko, Michael and Therese McGuire. 1985. "Jobs and Taxes: The Effect of Business Climate on States' Employment Growth Rates," National Tax Journal, 38, 497-511. 
TABLE 1: Business Climate Indexes ${ }^{\mathrm{a}}$

\begin{tabular}{|c|c|c|}
\hline Index, institution, and years & Stated focus of index & Policy categories \\
\hline $\begin{array}{l}\text { PROD1: State New Economy Index, } \\
\text { Progressive Policy Institute (1999, } \\
\text { 2002), Information, Technology and } \\
\text { Innovation Foundation and Kauffman } \\
\text { Foundation }(2007,2008)\end{array}$ & $\begin{array}{l}\text { Compatibility of state's economy } \\
\text { with "New Economy" }\end{array}$ & $\begin{array}{l}\text { Business incubation; human capital; } \\
\text { technology, knowledge jobs, and digital } \\
\text { economy, and external sector }\end{array}$ \\
\hline $\begin{array}{l}\text { PROD2: Development Report Card for the } \\
\text { States-Performance, Corporation for } \\
\text { Enterprise Development (2000-2007) }\end{array}$ & $\begin{array}{l}\text { Opportunities for employment, } \\
\text { income, and improving quality of } \\
\text { life }\end{array}$ & $\begin{array}{l}\text { Quality of life; equity; employment, earnings, } \\
\text { job quality, and resource } \\
\text { efficiency/environment }\end{array}$ \\
\hline $\begin{array}{l}\text { PROD3: Development Report Card for the } \\
\text { States-Development Capacity, } \\
\text { Corporation for Enterprise } \\
\text { Development (2000-2007) }\end{array}$ & Capacity for future development & $\begin{array}{l}\text { Cost of doing business (excl. taxes); quality of } \\
\text { life; business incubation; human capital; } \\
\text { infrastructure; technology, knowledge jobs, and } \\
\text { digital economy, and resource efficiency/ } \\
\text { environment }\end{array}$ \\
\hline $\begin{array}{l}\text { PROD4: Development Report Card for the } \\
\text { States-Business Vitality, } \\
\text { Corporation for Enterprise } \\
\text { Development (2000-2007) }\end{array}$ & $\begin{array}{l}\text { Dynamism of the state's large and } \\
\text { small businesses }\end{array}$ & $\begin{array}{l}\text { Business incubation; technology, knowledge } \\
\text { jobs, and digital economy, and external sector }\end{array}$ \\
\hline $\begin{array}{l}\text { PROD5: State Competitiveness Index, } \\
\text { Beacon Hill Institute (2001-2008) }\end{array}$ & $\begin{array}{l}\text { Long-term competitiveness for } \\
\text { attracting and incubating new } \\
\text { businesses and growth of existing } \\
\text { firms }\end{array}$ & $\begin{array}{l}\text { Cost of doing business; size of government; tax } \\
\text { rates and burden; quality of life; welfare and } \\
\text { transfer payments; employment, earnings, and } \\
\text { job quality; business incubation; human capital; } \\
\text { infrastructure; technology, knowledge jobs, and } \\
\text { digital economy, resource } \\
\text { efficiency/environment, and external sector }\end{array}$ \\
\hline $\begin{array}{l}\text { TXCST1: State Business Tax Climate } \\
\text { Index, Tax Foundation (2003-2009) }\end{array}$ & Tax rates & Tax rates and tax burden \\
\hline $\begin{array}{l}\text { TXCST2: Small Business Survival Index, } \\
\text { Small Business and Entrepreneurship } \\
\text { Council (1996-2008) }\end{array}$ & $\begin{array}{l}\text { Government-imposed or } \\
\text { government-related costs affecting } \\
\text { investment, entrepreneurship, and } \\
\text { business }\end{array}$ & $\begin{array}{l}\text { Cost of doing business (excl. taxes); size of } \\
\text { government; tax rates and tax burden; } \\
\text { regulation and litigation; quality of life; } \\
\text { infrastructure }\end{array}$ \\
\hline $\begin{array}{l}\text { TXCST3: Cost of Doing Business Index, } \\
\text { Milken Institute (2002-2007) }\end{array}$ & $\begin{array}{l}\text { Fundamental business costs, } \\
\text { including labor, taxes, real estate, } \\
\text { and electricity }\end{array}$ & $\begin{array}{l}\text { Cost of doing business (excl. taxes); tax rates } \\
\text { and tax burden }\end{array}$ \\
\hline $\begin{array}{l}\text { TXCST4: Economic Freedom Index, } \\
\text { Pacific Research Institute (1999, } \\
\text { 2004, 2008) }\end{array}$ & $\begin{array}{l}\text { Government favors free enterprise } \\
\text { and consumer choice; individual } \\
\text { rights to pursue interests through } \\
\text { voluntary exchange of private } \\
\text { property under rule of law }\end{array}$ & $\begin{array}{l}\text { Cost of doing business (excl. taxes); size of } \\
\text { government; tax rates and tax burden; } \\
\text { regulation and litigation; welfare and transfer } \\
\text { payments }\end{array}$ \\
\hline $\begin{array}{l}\text { TXCST5: Economic Freedom Index of } \\
\text { North America, The Fraser Institute / } \\
\text { National Center for Policy Analysis } \\
\text { (1992-2005) }\end{array}$ & $\begin{array}{l}\text { Restrictions on economic freedom } \\
\text { imposed by governments: takings } \\
\text { and discriminatory taxation; size of } \\
\text { government; and labor market } \\
\text { freedom }\end{array}$ & $\begin{array}{l}\text { Cost of doing business (excl. taxes); size of } \\
\text { government; tax rates and tax burden; welfare } \\
\text { and transfer payments }\end{array}$ \\
\hline $\begin{array}{l}\text { FISCPOL: Fiscal Policy Report Card on } \\
\text { the Nation's Governors, Cato } \\
\text { Institute (1992-2008, biennial) }\end{array}$ & $\begin{array}{l}\text { Fiscal performance of governors in } \\
\text { terms of restraining the growth of } \\
\text { taxes and spending }\end{array}$ & $\begin{array}{l}\text { Cost of doing business (excl. taxes); size of } \\
\text { government; tax rates and tax burden }\end{array}$ \\
\hline
\end{tabular}

${ }^{a}$ For the PROD1 index, the author of all four reports is the same (Robert Atkinson). The PROD2, PROD3, and PROD4 indexes go back earlier, but only the information beginning in 2000 was available on-line. The second column lists the focus of the index as stated by the creating institution. The third column gives our (more objective) categorization, although they are often the same as those used by the institutions that create the indexes.

Sources (for latest version of each index):

PROD1: http://www.kauffman.org/uploadedfiles/2008_state_new_economy_index_120908.pdf(viewed November, 2008); PROD2, PROD3, PROD4: http://www.cfed.org/focus.m?parentid=2\&siteid=2346\&id=2346 (viewed November, 2008); PROD5: http://www.beaconhill.org/compete08/BHIState08-FINAL.pdf (viewed November, 2008); TXCST1: http://www.taxfoundation.org/files/bp58.pdf (viewed November, 2008); TXCST2:

http://www.sbecouncil.org/uploads/sbsi\%202008\%5B1\%5D1.pdf (viewed December, 2008); TXCST3: http://www.milkeninstitute.org/pdf/2007CostofDoingBusiness.pdf (viewed November, 2008); TXCST4: http://special.pacificresearch.org/pub/sab/entrep/2008/Economic_Freedom/map.html (viewed November, 2008); TXCST5: http://www.freetheworld.com/efna2008/EFNA_complete_Publication.pdf (viewed November, 2008); FISCPOL: http://www.cato.org/pubs/pas/pa-624.pdf (viewed November, 2008). 
TABLE 2: Average State Ranks by Index, 1992-2009ª

\begin{tabular}{|c|c|c|c|c|c|}
\hline State & $\begin{array}{c}\text { Average rank } \\
\text { across PROD } \\
\text { indexes }\end{array}$ & $\begin{array}{c}\text { Average rank } \\
\text { across TXCST } \\
\text { indexes }\end{array}$ & FISCPOL & $\begin{array}{l}\text { Min of } \\
\text { all } \\
\text { indexes }\end{array}$ & $\begin{array}{l}\text { Max of } \\
\text { all } \\
\text { indexes }\end{array}$ \\
\hline Alabama & 38.4 & 14.2 & 32 & 9 & 45 \\
\hline Alaska & 34.3 & 28.9 & & 3 & 46 \\
\hline Arizona & 30.1 & 20.6 & 27 & 7 & 37 \\
\hline Arkansas & 42 & 23.2 & 27 & 11 & 48 \\
\hline California & 15.3 & 45.6 & 31 & 4 & 47 \\
\hline Colorado & 6.4 & 13.5 & 14 & 1 & 26 \\
\hline Connecticut & 8.9 & 38.4 & 21 & 5 & 47 \\
\hline Delaware & 10.4 & 18.3 & 35 & 2 & 42 \\
\hline Florida & 28.9 & 14.6 & 16 & 5 & 33 \\
\hline Georgia & 25.6 & 19.1 & 17 & 11 & 32 \\
\hline Hawaii & 39.3 & 38.9 & 25 & 23 & 49 \\
\hline Idaho & 22.4 & 20.4 & 26 & 2 & 34 \\
\hline Illinois & 23.3 & 27.6 & 30 & 10 & 37 \\
\hline Indiana & 31.9 & 14.9 & 17 & 11 & 36 \\
\hline Iowa & 26.2 & 27.2 & 30 & 5 & 44 \\
\hline Kansas & 23.6 & 22.2 & 27 & 7 & 35 \\
\hline Kentucky & 37.5 & 27.9 & 19 & 15 & 43 \\
\hline Louisiana & 45.5 & 26.1 & 34 & 14 & 50 \\
\hline Maine & 28 & 39.1 & 25 & 14 & 47 \\
\hline Maryland & 12.7 & 29.1 & 30 & 5 & 38 \\
\hline Massachusetts & 4.4 & 35 & 11 & 1 & 48 \\
\hline Michigan & 25.2 & 29.4 & 16 & 12 & 40 \\
\hline Minnesota & 6.7 & 40.6 & 19 & 1 & 46 \\
\hline Mississippi & 47.8 & 16.4 & 17 & 10 & 50 \\
\hline Missouri & 29 & 15.8 & 27 & 13 & 34 \\
\hline Montana & 33.4 & 22.7 & 29 & 4 & 43 \\
\hline Nebraska & 23.5 & 25.1 & 20 & 10 & 44 \\
\hline Nevada & 32.4 & 13.3 & 20 & 2 & 42 \\
\hline New Hampshire & 11.9 & 13.1 & 18 & 1 & 33 \\
\hline New Jersey & 15.6 & 43.3 & 28 & 5 & 48 \\
\hline New Mexico & 36.8 & 34.5 & 13 & 13 & 46 \\
\hline New York & 21.6 & 48.2 & 12 & 12 & 50 \\
\hline North Carolina & 29.5 & 28.6 & 31 & 13 & 42 \\
\hline North Dakota & 29.9 & 21.8 & 25 & 2 & 44 \\
\hline Ohio & 28.8 & 38.2 & 33 & 18 & 47 \\
\hline Oklahoma & 37.6 & 19.1 & 20 & 8 & 42 \\
\hline Oregon & 17.8 & 27.7 & 39 & 9 & 40 \\
\hline Pennsylvania & 19.3 & 30.3 & 23 & 10 & 45 \\
\hline Rhode Island & 23.7 & 45.7 & 26 & 13 & 49 \\
\hline South Carolina & 34.5 & 15 & 13 & 8 & 40 \\
\hline South Dakota & 30.1 & 3.7 & 11 & 1 & 46 \\
\hline Tennessee & 33.1 & 12.9 & 23 & 1 & 39 \\
\hline Texas & 24.8 & 12.6 & 13 & 5 & 47 \\
\hline Utah & 11.2 & 15.5 & 21 & 4 & 26 \\
\hline Vermont & 18.1 & 39.6 & 22 & 3 & 43 \\
\hline Virginia & 9.8 & 13.8 & 26 & 5 & 30 \\
\hline Washington & 11.5 & 26.1 & 21 & 3 & 40 \\
\hline West Virginia & 47.8 & 33.5 & 29 & 14 & 49 \\
\hline Wisconsin & 20.2 & 32.6 & 21 & 8 & 38 \\
\hline Wyoming & 28.1 & 11.2 & 26 & 1 & 46 \\
\hline
\end{tabular}

${ }^{a}$ We first average each index across years, and then average these averages to get the numbers reported in the first two columns. The last two columns report the minimum and maximum of the averages of each individual index. 
TABLE 3: Descriptive Statistics for Growth Measures and Control Variables ${ }^{\mathrm{a}}$

\begin{tabular}{|c|c|c|c|c|c|c|}
\hline Variable & Source & $\mathbf{N}$ & Mean & $\begin{array}{l}\text { Std. } \\
\text { dev. }\end{array}$ & Min. & Max. \\
\hline Growth rates & & & & & & \\
\hline Employment & BLS-QCEW & 768 & 1.61 & 1.71 & -3.51 & 10.17 \\
\hline Total wages & BLS-QCEW & 768 & 5.26 & 2.56 & -2.63 & 15.67 \\
\hline Gross State Product (GSP) & BEA & 528 & 5.07 & 2.40 & -3.21 & 14.10 \\
\hline $\begin{array}{l}\text { Employment change due to } \\
\text { births }\end{array}$ & NETS & 672 & 5.14 & 1.78 & 2.24 & 13.36 \\
\hline Controls & & & & & & \\
\hline Industry composition & NETS & 768 & 0.98 & 0.17 & 0.61 & 1.41 \\
\hline Population density (logs) & $\begin{array}{l}\text { Census of } \\
\text { Population }\end{array}$ & 768 & 7.74 & 0.74 & 6.62 & 10.22 \\
\hline Dry & $\begin{array}{l}\text { Mendelsohn et } \\
\text { al. (1994) }\end{array}$ & 768 & -7.54 & 2.90 & -12.09 & -1.70 \\
\hline Mild & $\begin{array}{l}\text { Mendelsohn et } \\
\text { al. (1994) }\end{array}$ & 768 & -40.05 & 11.25 & -62.68 & -17.12 \\
\hline Proximity & $\begin{array}{l}\text { Rappaport and } \\
\text { Sachs (2003) }\end{array}$ & 768 & -189.96 & 238.36 & -959.02 & -10.14 \\
\hline
\end{tabular}

\footnotetext{
${ }^{a}$ Employment, wages, and GSP growth are one-year percent changes, multiplied by 100. Employment due to births is the percentage growth in total employment attributable to births, and equals the change in employment due to births relative to startyear total employment (multiplied by 100). The births measure exceeds the overall percent change in employment because it is a gross job flow. The descriptive statistics in this table cover 1992-2006 for NETS employment change due to births; 1992-2008 for QCEW employment and wages; and 1997-2008 for GSP. The control variables are defined as the negatives of measures of precipitation, temperature extremes, and distance to water; therefore more positive values imply drier, milder, and closer to water. In the regressions in tables that follow, subsets of the observations are used, depending on the years in which an index is available. Alaska and Hawaii are excluded from the descriptive statistics as well as the regressions that follow because some of the control variables are unavailable; however, they are included in the industry composition effect calculation. "Mean" refers to the unweighted average of state values for each variable.
} 
TABLE 4: Distribution of Weights of Components of Business Climate Indexes (\%) ${ }^{\mathrm{a}}$

\begin{tabular}{|c|c|c|c|c|c|c|c|c|c|c|c|}
\hline & PROD1 & PROD2 & PROD3 & PROD4 & PROD5 & TXCST1 & TXCST2 & TXCST3 & TXCST4 & TXCST5 & FISCPOL \\
\hline $\begin{array}{l}\text { Taxes and costs category } \\
\text { Cost of doing business } \\
\text { (excluding taxes) } \\
\text { Size of government } \\
\text { Tax rates and tax burden } \\
\text { Regulation and litigation } \\
\text { Welfare and transfer } \\
\text { payments }\end{array}$ & 0.0 & 0.0 & $\begin{array}{l}4.0 \\
4.0\end{array}$ & 0.0 & $\begin{array}{c}20.9 \\
9.3 \\
\\
7.0 \\
2.3 \\
\\
2.3\end{array}$ & 100.0 & $\begin{array}{c}94.1 \\
8.8 \\
\\
8.8 \\
47.1 \\
29.4\end{array}$ & $\begin{array}{c}100.0 \\
80.0\end{array}$ & $\begin{array}{c}100.0 \\
1.3 \\
14.7 \\
19.2 \\
40.5 \\
24.3\end{array}$ & $\begin{array}{c}100.0 \\
22.2 \\
\\
22.2 \\
33.3 \\
22.2\end{array}$ & $\begin{array}{l}66.7 \\
33.3\end{array}$ \\
\hline $\begin{array}{l}\text { Productivity category } \\
\text { Quality of life } \\
\text { Equity } \\
\text { Employment, earnings and } \\
\text { job quality } \\
\text { Business incubation } \\
\text { Human capital } \\
\text { Infrastructure } \\
\text { Technology, knowledge } \\
\text { jobs, and digital economy }\end{array}$ & $\begin{array}{c}25.1 \\
3.4 \\
61.8\end{array}$ & $\begin{array}{l}80.0 \\
20.0 \\
20.0 \\
40.0\end{array}$ & $\begin{array}{l}20.0 \\
20.0 \\
20.0 \\
20.0\end{array}$ & $\begin{array}{l}52.5 \\
22.5\end{array}$ & $\begin{array}{c}65.1 \\
23.3 \\
\\
4.7 \\
\\
9.3 \\
7.0 \\
2.3 \\
18.6\end{array}$ & 0.0 & $\begin{array}{l}5.9 \\
2.9\end{array}$ & 0.0 & 0.0 & 0.0 & 0.0 \\
\hline $\begin{array}{l}\text { “Other” category } \\
\text { Resource efficiency / } \\
\text { environment } \\
\text { External sector }\end{array}$ & 9.6 & $\begin{array}{l}20.0 \\
20.0\end{array}$ & $\begin{array}{l}4.0 \\
4.0\end{array}$ & 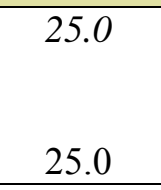 & $\begin{array}{c}14.0 \\
7.0 \\
7.0 \\
\end{array}$ & 0.0 & 0.0 & 0.0 & 0.0 & 0.0 & 0.0 \\
\hline
\end{tabular}

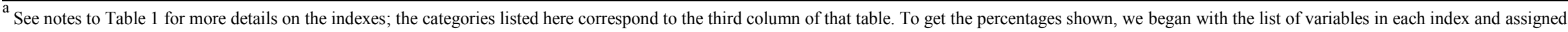

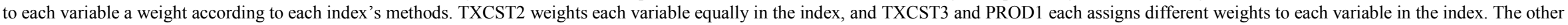

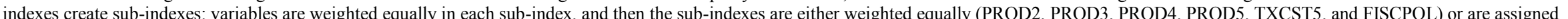

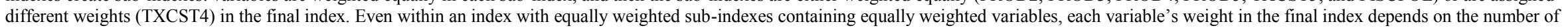
variables in its sub-index. All of the TXCST1 variables fall under the "tax rates and tax burden" category, making it unnecessary to replicate the index's weighting scheme for this table. 
TABLE 5: Correlations of Average Indexes across States, 1992-2009

\begin{tabular}{|c|c|c|c|c|c|c|c|c|c|c|}
\hline & PROD1 & PROD2 & PROD3 & PROD4 & PROD5 & TXCST1 & TXCST2 & TXCST3 & TXCST4 & TXCST5 \\
\hline PROD1 & 1 & & & & & & & & & \\
\hline PROD2 & $.56^{*}$ & 1 & & & & & & & & \\
\hline PROD3 & $.76^{*}$ & $.72 *$ & 1 & & & & & & & \\
\hline PROD4 & $.72 *$ & $.30 *$ & $.58 *$ & 1 & & & & & & \\
\hline PROD5 & $.61^{*}$ & $.75^{*}$ & $.77^{*}$ & $.31^{*}$ & 1 & & & & & \\
\hline TXCST1 & -.12 & -.05 & -.12 & -.24 & .18 & 1 & & & & \\
\hline TXCST2 & -.17 & -.11 & -.13 & -.09 & .04 & $.79 *$ & 1 & & & \\
\hline TXCST3 & $-.65^{*}$ & $-.29 *$ & $-.30 *$ & $-.37^{*}$ & -.12 & .25 & $.39 *$ & 1 & & \\
\hline TXCST4 & $-.30 *$ & -.01 & -.15 & -.17 & .19 & $.55^{*}$ & $.54 *$ & $.66^{*}$ & 1 & \\
\hline TXCST5 & .04 & -.01 & .03 & .26 & .10 & $.41^{*}$ & $.61^{*}$ & $.33 *$ & $.60^{*}$ & 1 \\
\hline FISCPOL & .14 & .11 & .02 & .16 & .16 & .22 & $.35^{*}$ & -.11 & .07 & .17 \\
\hline
\end{tabular}

${ }^{\text {a }}$ Table reports correlations of the average across years for each index. * indicates statistically significantly different from zero at the 5-percent level. All 50 states are included. 
TABLE 6: Regressions for Yearly QCEW Employment Growth, 1992-2008 ${ }^{\text {a }}$

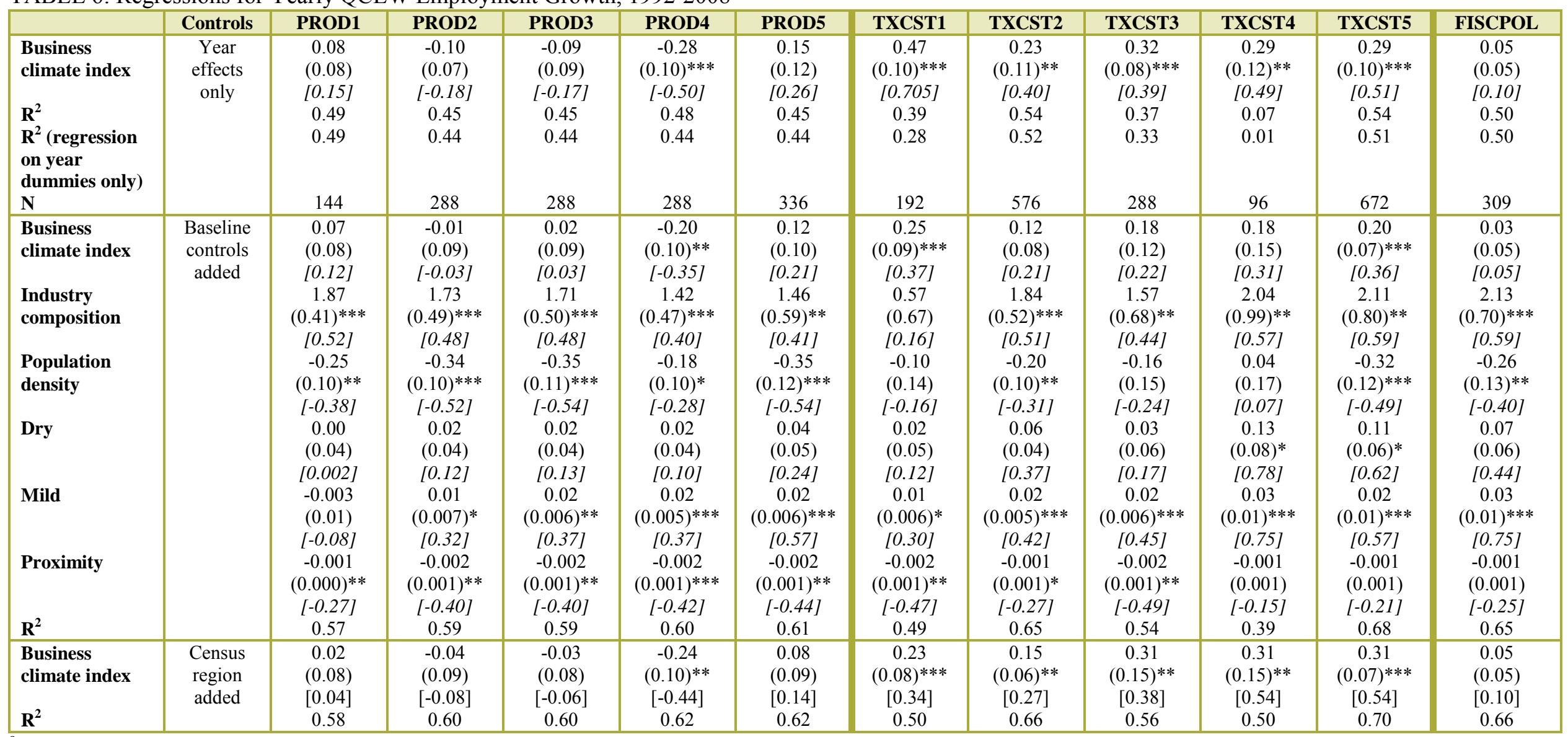

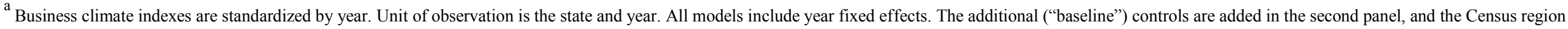

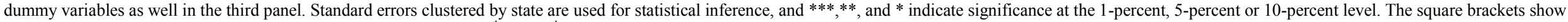
the estimated coefficients multiplied by the difference between the $10^{\text {th }}$ and $40^{\text {th }}$ state rankings for each variable. Hawaii and Alaska are excluded. Population density is entered in logs.

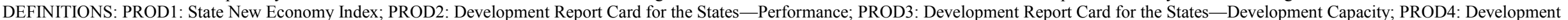

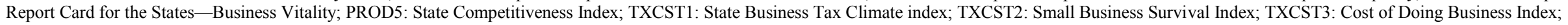

TXCST4: Economic Freedom Index; TXCST5: Economic Freedom Index of North America; FISCPOL: Fiscal Policy Report Card. 
TABLE 7: Regressions for Yearly QCEW Wage Growth 1992-2008, and GSP Growth, 1997-2008

\begin{tabular}{|c|c|c|c|c|c|c|c|c|c|c|c|c|}
\hline & Controls & PROD1 & PROD2 & PROD3 & PROD4 & PROD5 & TXCST1 & TXCST2 & TXCST3 & TXCST4 & TXCST5 & FISCPOL \\
\hline \multicolumn{13}{|c|}{ A. QCEW Wage Growth } \\
\hline $\begin{array}{l}\text { Business climate } \\
\text { index } \\
\mathbf{R}^{2} \\
\mathbf{R}^{2} \text { (regression } \\
\text { on year } \\
\text { dummies only) } \\
\mathbf{N}\end{array}$ & $\begin{array}{c}\text { Year } \\
\text { effects only }\end{array}$ & $\begin{array}{c}0.26 \\
(0.14)^{*} \\
{[0.49]} \\
0.53 \\
0.52\end{array}$ & $\begin{array}{c}-0.17 \\
(0.11)^{*} \\
{[-0.31]} \\
0.48 \\
0.47\end{array}$ & $\begin{array}{c}-0.25 \\
(0.12)^{* *} \\
{[-0.47]} \\
0.48 \\
0.47\end{array}$ & $\begin{array}{c}-0.57 \\
(0.16)^{* * *} \\
{[-1.03]} \\
0.53 \\
0.47\end{array}$ & $\begin{array}{c}0.09 \\
(0.16) \\
{[0.16]} \\
0.49 \\
0.49\end{array}$ & $\begin{array}{c}0.65 \\
(0.22)^{* * *} \\
{[0.96]} \\
0.37 \\
0.29\end{array}$ & $\begin{array}{c}0.29 \\
(0.14)^{* *} \\
{[0.51]} \\
0.55 \\
0.54\end{array}$ & $\begin{array}{c}0.34 \\
(0.13)^{* *} \\
{[0.43]} \\
0.39 \\
0.37\end{array}$ & $\begin{array}{c}0.24 \\
(0.24) \\
{[0.41]} \\
0.18 \\
0.17\end{array}$ & $\begin{array}{c}0.42 \\
(0.11)^{* * *} \\
{[0.74]} \\
0.53 \\
0.50\end{array}$ & $\begin{array}{c}0.09 \\
(0.09) \\
{[0.20]} \\
0.48 \\
0.48\end{array}$ \\
\hline $\begin{array}{l}\text { Business climate } \\
\text { index } \\
\mathbf{R}^{2}\end{array}$ & $\begin{array}{l}\text { Baseline } \\
\text { controls } \\
\text { added }\end{array}$ & $\begin{array}{c}0.26 \\
(0.16) \\
{[0.50]} \\
0.58\end{array}$ & $\begin{array}{c}-0.15 \\
(0.17) \\
{[-0.28]} \\
0.58\end{array}$ & $\begin{array}{c}-0.21 \\
(0.14) \\
{[-0.40]} \\
0.58\end{array}$ & $\begin{array}{c}-0.47 \\
(0.14)^{* * *} \\
{[-0.85]} \\
0.61\end{array}$ & $\begin{array}{c}-0.02 \\
(0.14) \\
{[-0.04]} \\
0.61\end{array}$ & $\begin{array}{c}0.28 \\
(0.18) \\
{[0.41]} \\
0.47\end{array}$ & $\begin{array}{c}0.16 \\
(0.11) \\
{[0.29]} \\
0.62\end{array}$ & $\begin{array}{c}0.12 \\
(0.24) \\
{[0.15]} \\
0.54\end{array}$ & $\begin{array}{c}0.19 \\
(0.24) \\
{[0.33]} \\
0.49\end{array}$ & $\begin{array}{c}0.36 \\
(0.08)^{* * *} \\
{[0.63]} \\
0.61\end{array}$ & $\begin{array}{c}0.06 \\
(0.09) \\
{[0.13]} \\
0.56\end{array}$ \\
\hline $\begin{array}{l}\text { Business climate } \\
\text { index } \\
\mathbf{R}^{2}\end{array}$ & $\begin{array}{l}\text { Census } \\
\text { region } \\
\text { added }\end{array}$ & $\begin{array}{c}0.23 \\
(0.16) \\
{[0.43]} \\
0.59 \\
\end{array}$ & $\begin{array}{c}-0.17 \\
(0.16) \\
{[-0.33]} \\
0.59\end{array}$ & $\begin{array}{c}-0.24 \\
(0.14)^{*} \\
{[-0.44]} \\
0.59 \\
\end{array}$ & $\begin{array}{c}-0.54 \\
(0.15)^{* * *} \\
{[-0.98]} \\
0.62\end{array}$ & $\begin{array}{c}-0.04 \\
(0.13) \\
{[-0.08]} \\
0.62\end{array}$ & $\begin{array}{c}0.30 \\
(0.17)^{*} \\
{[0.44]} \\
0.48 \\
\end{array}$ & $\begin{array}{c}0.21 \\
(0.10)^{* *} \\
{[0.38]} \\
0.63 \\
\end{array}$ & $\begin{array}{c}0.30 \\
(0.30) \\
{[0.37]} \\
0.55 \\
\end{array}$ & $\begin{array}{c}0.47 \\
(0.22)^{* *} \\
{[0.81]} \\
0.56 \\
\end{array}$ & $\begin{array}{c}0.49 \\
(0.07)^{* * *} \\
{[0.86]} \\
0.62 \\
\end{array}$ & $\begin{array}{c}0.08 \\
(0.10) \\
{[0.16]} \\
0.57 \\
\end{array}$ \\
\hline \multicolumn{13}{|l|}{ B. GSP Growth } \\
\hline $\begin{array}{l}\text { Business climate } \\
\text { index } \\
\mathbf{R}^{2} \\
\mathbf{R}^{2} \text { (regression } \\
\text { on year } \\
\text { dummies only) } \\
\mathbf{N}\end{array}$ & $\begin{array}{c}\text { Year } \\
\text { effects only }\end{array}$ & $\begin{array}{c}-0.06 \\
(0.21) \\
{[-0.12]} \\
0.11 \\
0.11\end{array}$ & $\begin{array}{c}-0.27 \\
(0.15)^{*} \\
{[-0.50]} \\
0.23 \\
0.21\end{array}$ & $\begin{array}{c}-0.36 \\
(0.16)^{* *} \\
{[-0.68]} \\
0.23 \\
0.21\end{array}$ & $\begin{array}{c}-0.69 \\
(0.19)^{* * *} \\
{[-1.25]} \\
0.29 \\
0.21\end{array}$ & $\begin{array}{c}0.08 \\
(0.19) \\
{[0.13]} \\
0.19 \\
0.19\end{array}$ & $\begin{array}{c}0.78 \\
(0.20)^{* * *} \\
{[1.15]} \\
0.29 \\
0.21\end{array}$ & $\begin{array}{c}0.34 \\
(0.16)^{* *} \\
{[0.59]} \\
0.19 \\
0.17\end{array}$ & $\begin{array}{c}0.47 \\
(0.16)^{* * *} \\
{[0.58]} \\
0.19 \\
0.16\end{array}$ & $\begin{array}{c}0.36 \\
(0.27) \\
{[0.62]} \\
0.04 \\
0.02\end{array}$ & $\begin{array}{c}0.34 \\
(0.13)^{* *} \\
{[0.60]} \\
0.19 \\
0.17\end{array}$ & $\begin{array}{c}0.17 \\
(0.16) \\
{[0.35]} \\
0.13 \\
0.12\end{array}$ \\
\hline $\begin{array}{l}\text { Business climate } \\
\text { index } \\
\mathbf{R}^{2}\end{array}$ & $\begin{array}{l}\text { Baseline } \\
\text { controls } \\
\text { added }\end{array}$ & $\begin{array}{c}-0.23 \\
(0.24) \\
{[-0.43]} \\
0.26\end{array}$ & $\begin{array}{c}-0.27 \\
(0.20) \\
{[-0.51]} \\
0.37\end{array}$ & $\begin{array}{c}-0.28 \\
(0.16)^{*} \\
{[-0.52]} \\
0.37\end{array}$ & $\begin{array}{c}-0.55 \\
(0.15)^{* * *} \\
{[-0.99]} \\
0.40\end{array}$ & $\begin{array}{c}0.01 \\
(0.16) \\
{[0.01]} \\
0.34\end{array}$ & $\begin{array}{c}0.27 \\
(0.21) \\
{[0.39]} \\
0.40\end{array}$ & $\begin{array}{c}0.18 \\
(0.14) \\
{[0.31]} \\
0.28\end{array}$ & $\begin{array}{c}0.33 \\
(0.25) \\
{[0.41]} \\
0.36\end{array}$ & $\begin{array}{c}0.18 \\
(0.33) \\
{[0.32]} \\
0.36\end{array}$ & $\begin{array}{c}0.19 \\
(0.11)^{*} \\
{[0.34]} \\
0.29\end{array}$ & $\begin{array}{c}0.13 \\
(0.16) \\
{[0.27]} \\
0.28\end{array}$ \\
\hline $\begin{array}{l}\text { Business climate } \\
\text { index } \\
\mathbf{R}^{2}\end{array}$ & $\begin{array}{l}\text { Census } \\
\text { region } \\
\text { added }\end{array}$ & $\begin{array}{c}-0.17 \\
(0.27) \\
{[-0.33]} \\
0.28\end{array}$ & $\begin{array}{c}-0.23 \\
(0.19) \\
{[-0.44]} \\
0.38\end{array}$ & $\begin{array}{c}-0.34 \\
(0.17)^{* *} \\
{[-0.63]} \\
0.38\end{array}$ & $\begin{array}{c}-0.59 \\
(0.15)^{* * *} \\
{[-1.07]} \\
0.41\end{array}$ & $\begin{array}{c}0.001 \\
(0.16) \\
{[0.00]} \\
0.35\end{array}$ & $\begin{array}{c}0.25 \\
(0.21) \\
{[0.37]} \\
0.41\end{array}$ & $\begin{array}{c}0.21 \\
(0.14) \\
{[0.37]} \\
0.29\end{array}$ & $\begin{array}{c}0.43 \\
(0.29) \\
{[0.54]} \\
0.37\end{array}$ & $\begin{array}{c}0.34 \\
(0.32) \\
{[0.58]} \\
0.39\end{array}$ & $\begin{array}{c}0.30 \\
(0.11)^{* *} \\
{[0.52]} \\
0.31\end{array}$ & $\begin{array}{c}0.11 \\
(0.14) \\
{[0.23]} \\
0.31\end{array}$ \\
\hline
\end{tabular}

${ }^{\mathrm{a}}$ See notes to Table 6 . The estimated coefficients of the baseline controls are not reported.

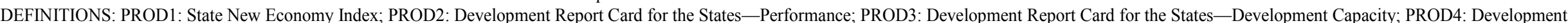

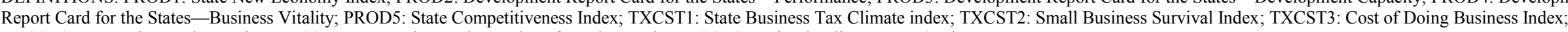
TXCST4: Economic Freedom Index; TXCST5: Economic Freedom Index of North America; FISCPOL: Fiscal Policy Report Card. 
TABLE 8: Regressions for Employment Growth Due to Births, 1992-2006 ${ }^{\mathrm{a}}$

\begin{tabular}{|c|c|c|c|c|c|c|c|c|c|c|c|c|}
\hline & Controls & PROD1 & PROD2 & PROD3 & PROD4 & PROD5 & TXCST1 & TXCST2 & TXCST3 & TXCST4 & TXCST5 & FISCPOL \\
\hline $\begin{array}{l}\text { Business climate } \\
\text { index } \\
\mathbf{R}^{2} \\
\mathbf{R}^{2} \text { (regression } \\
\text { on year } \\
\text { dummies only) } \\
\mathbf{N}\end{array}$ & $\begin{array}{c}\text { Year } \\
\text { effects only }\end{array}$ & $\begin{array}{c}0.15 \\
(0.10) \\
{[0.29]} \\
0.79 \\
0.78\end{array}$ & $\begin{array}{c}-0.09 \\
(0.08) \\
{[-0.18]} \\
0.22 \\
0.21\end{array}$ & $\begin{array}{c}-0.04 \\
(0.09) \\
{[-0.08]} \\
0.21 \\
0.21\end{array}$ & $\begin{array}{c}0.08 \\
(0.09) \\
{[0.14]} \\
0.21 \\
0.21\end{array}$ & $\begin{array}{c}-0.02 \\
(0.09) \\
{[-0.04]} \\
0.29 \\
0.29\end{array}$ & $\begin{array}{c}0.33 \\
(0.12)^{* * *} \\
{[0.47]} \\
0.32 \\
0.19\end{array}$ & $\begin{array}{c}0.26 \\
(0.12)^{* *} \\
{[0.47]} \\
0.69 \\
0.67\end{array}$ & $\begin{array}{c}0.05 \\
(0.07) \\
{[0.06]} \\
0.33 \\
0.33\end{array}$ & $\begin{array}{c}0.37 \\
(0.11)^{* * *} \\
{[0.63]} \\
0.62 \\
0.56\end{array}$ & $\begin{array}{c}0.33 \\
(0.09)^{* * *} \\
{[0.58]} \\
0.69 \\
0.65\end{array}$ & $\begin{array}{c}0.02 \\
(0.09) \\
{[0.05]} \\
0.60 \\
0.60\end{array}$ \\
\hline $\begin{array}{l}\text { Business climate } \\
\text { index } \\
\mathbf{R}^{2}\end{array}$ & $\begin{array}{l}\text { Baseline } \\
\text { controls } \\
\text { added }\end{array}$ & $\begin{array}{c}0.20 \\
(0.09)^{* *} \\
{[0.38]} \\
0.88\end{array}$ & $\begin{array}{c}0.28 \\
(0.08)^{* * *} \\
{[0.54]} \\
0.57\end{array}$ & $\begin{array}{c}0.17 \\
(0.08)^{* *} \\
{[0.34]} \\
0.54\end{array}$ & $\begin{array}{c}0.13 \\
(0.07)^{*} \\
{[0.23]} \\
0.53\end{array}$ & $\begin{array}{c}0.13 \\
(0.08) \\
{[0.22]} \\
0.59\end{array}$ & $\begin{array}{c}0.16 \\
(0.10)^{*} \\
{[0.23]} \\
0.58\end{array}$ & $\begin{array}{c}0.13 \\
(0.09) \\
{[0.24]} \\
0.80\end{array}$ & $\begin{array}{c}-0.06 \\
(0.08) \\
{[-0.08]} \\
0.66\end{array}$ & $\begin{array}{c}0.37 \\
(0.14)^{* * *} \\
{[0.64]} \\
0.77\end{array}$ & $\begin{array}{c}0.14 \\
(0.07)^{*} \\
{[0.25]} \\
0.78\end{array}$ & $\begin{array}{c}-0.01 \\
(0.07) \\
{[-0.01]} \\
0.74\end{array}$ \\
\hline $\begin{array}{l}\text { Business climate } \\
\text { index } \\
\mathbf{R}^{2}\end{array}$ & $\begin{array}{l}\text { Plus } \\
\text { Census } \\
\text { region }\end{array}$ & $\begin{array}{c}0.22 \\
(0.08)^{* *} \\
{[0.41]} \\
0.90\end{array}$ & $\begin{array}{c}0.27 \\
(0.09)^{* * *} \\
{[0.52]} \\
0.58\end{array}$ & $\begin{array}{c}0.15 \\
(0.08)^{*} \\
{[0.29]} \\
0.56\end{array}$ & $\begin{array}{c}0.10 \\
(0.06) \\
{[0.18]} \\
0.55\end{array}$ & $\begin{array}{c}0.09 \\
(0.08) \\
{[0.16]} \\
0.61\end{array}$ & $\begin{array}{c}0.15 \\
(0.10) \\
{[0.21]} \\
0.60\end{array}$ & $\begin{array}{c}0.14 \\
(0.08)^{*} \\
{[0.26]} \\
0.81\end{array}$ & $\begin{array}{c}-0.04 \\
(0.10) \\
{[-0.05]} \\
0.68\end{array}$ & $\begin{array}{c}0.38 \\
(0.13)^{* * *} \\
{[0.65]} \\
0.80\end{array}$ & $\begin{array}{c}0.21 \\
(0.08)^{* * *} \\
{[0.37]} \\
0.80\end{array}$ & $\begin{array}{c}0.02 \\
(0.06) \\
{[0.05]} \\
0.75\end{array}$ \\
\hline
\end{tabular}

See notes to Table 6 . The estimated coefficients of the baseline controls are not reported.

Definitions: PROD1: State New Economy Index; PROD2: Development Report Card for the States—Performance; PROD3: Development Report Card for the States—Development Capacity; PROD4:

Development Report Card for the States—Business Vitality; PROD5: State Competitiveness Index; TXCST1: State Business Tax Climate index; TXCST2: Small Business Survival Index; TXCST3: Cost of

Doing Business Index; TXCST4: Economic Freedom Index; TXCST5: Economic Freedom Index of North America; FISCPOL: Fiscal Policy Report Card. 
TABLE 9: Regressions for QCEW Employment and Wages in Manufacturing and Footloose Industries, 1992-2008

\begin{tabular}{|c|c|c|c|c|c|c|c|c|c|c|c|}
\hline Industry & PROD1 & PROD2 & PROD3 & PROD4 & PROD5 & TXCST1 & TXCST2 & TXCST3 & TXCST4 & TXCST5 & FISCPOL \\
\hline \multicolumn{12}{|l|}{ A. Employment } \\
\hline Total private & $\begin{array}{c}0.06 \\
(0.09) \\
{[0.11]}\end{array}$ & $\begin{array}{c}-0.05 \\
(0.10) \\
{[-0.09]}\end{array}$ & $\begin{array}{c}-0.001 \\
(0.09) \\
{[-0.00]}\end{array}$ & $\begin{array}{c}-0.25 \\
(0.11)^{* *} \\
{[-0.457]}\end{array}$ & $\begin{array}{c}0.11 \\
(0.11) \\
{[0.19]}\end{array}$ & $\begin{array}{c}0.26 \\
(0.10)^{* *} \\
{[0.39]}\end{array}$ & $\begin{array}{c}0.13 \\
(0.08) \\
{[0.23]}\end{array}$ & $\begin{array}{c}0.22 \\
(0.14) \\
{[0.28]}\end{array}$ & $\begin{array}{c}0.17 \\
(0.17) \\
{[0.29]}\end{array}$ & $\begin{array}{c}0.22 \\
(0.08)^{* * *} \\
{[0.38]}\end{array}$ & $\begin{array}{c}0.02 \\
(0.06) \\
{[0.04]}\end{array}$ \\
\hline Manufacturing & $\begin{array}{c}-0.29 \\
(0.22) \\
{[-0.56]}\end{array}$ & $\begin{array}{c}-0.27 \\
(0.27) \\
{[-0.51]}\end{array}$ & $\begin{array}{c}-0.10 \\
(0.24) \\
{[-0.18]}\end{array}$ & $\begin{array}{c}-0.56 \\
(0.18)^{* * *} \\
{[-1.01]}\end{array}$ & $\begin{array}{c}0.05 \\
(0.23) \\
{[0.09]}\end{array}$ & $\begin{array}{c}0.53 \\
(0.21)^{* *} \\
{[0.78]}\end{array}$ & $\begin{array}{c}0.33 \\
(0.15)^{* *} \\
{[0.58]}\end{array}$ & $\begin{array}{c}0.86 \\
(0.26)^{* * *} \\
{[1.07]}\end{array}$ & $\begin{array}{c}-0.09 \\
(0.36) \\
{[-0.15]}\end{array}$ & $\begin{array}{c}0.28 \\
(0.15)^{*} \\
{[0.49]}\end{array}$ & $\begin{array}{c}0.03 \\
(0.11) \\
{[0.07]}\end{array}$ \\
\hline $\begin{array}{l}\text { Footloose } \\
\text { industries }\end{array}$ & $\begin{array}{c}0.33 \\
(0.19)^{*} \\
{[0.63]}\end{array}$ & $\begin{array}{c}-0.05 \\
(0.20) \\
{[-0.09]}\end{array}$ & $\begin{array}{l}0.002 \\
(0.15) \\
{[0.00]}\end{array}$ & $\begin{array}{c}-0.27 \\
(0.16)^{*} \\
{[-0.49]}\end{array}$ & $\begin{array}{c}0.20 \\
(0.14) \\
{[0.34]}\end{array}$ & $\begin{array}{c}0.24 \\
(0.15) \\
{[0.35]}\end{array}$ & $\begin{array}{c}0.20 \\
(0.12) \\
{[0.34]}\end{array}$ & $\begin{array}{c}0.38 \\
(0.14)^{* *} \\
{[0.47]}\end{array}$ & $\begin{array}{c}0.05 \\
(0.46) \\
{[0.08]}\end{array}$ & $\begin{array}{c}0.25 \\
(0.12)^{* *} \\
{[0.44]}\end{array}$ & $\begin{array}{c}0.20 \\
(0.15) \\
{[0.41]}\end{array}$ \\
\hline \multicolumn{12}{|l|}{ B. Wages } \\
\hline Total private & $\begin{array}{c}0.33 \\
(0.18)^{*} \\
{[0.62]}\end{array}$ & $\begin{array}{c}-0.20 \\
(0.19) \\
{[-0.38]}\end{array}$ & $\begin{array}{c}-0.25 \\
(0.15)^{*} \\
{[-0.46]}\end{array}$ & $\begin{array}{c}-0.56 \\
(0.16)^{* * *} \\
{[-1.00]}\end{array}$ & $\begin{array}{c}-0.08 \\
(0.15) \\
{[-0.13]}\end{array}$ & $\begin{array}{c}0.30 \\
(0.21) \\
{[0.45]}\end{array}$ & $\begin{array}{c}0.19 \\
(0.13) \\
{[0.33]}\end{array}$ & $\begin{array}{c}0.19 \\
(0.28) \\
{[0.23]} \\
\end{array}$ & $\begin{array}{c}0.21 \\
(0.27) \\
{[0.36]} \\
\end{array}$ & $\begin{array}{c}0.40 \\
(0.09)^{* * *} \\
{[0.70]}\end{array}$ & $\begin{array}{c}0.08 \\
(0.11) \\
{[0.16]}\end{array}$ \\
\hline Manufacturing & $\begin{array}{c}0.19 \\
(0.40) \\
{[0.36]}\end{array}$ & $\begin{array}{l}-0.22 \\
(0.36) \\
{[-0.41]}\end{array}$ & $\begin{array}{c}-0.18 \\
(0.27) \\
{[-0.33]}\end{array}$ & $\begin{array}{c}-0.65 \\
(0.22)^{* * *} \\
{[-1.17]}\end{array}$ & $\begin{array}{c}0.14 \\
(0.26) \\
{[0.25]}\end{array}$ & $\begin{array}{c}0.69 \\
(0.26)^{* *} \\
{[1.02]}\end{array}$ & $\begin{array}{c}0.34 \\
(0.17)^{*} \\
{[0.59]}\end{array}$ & $\begin{array}{c}0.64 \\
(0.35)^{*} \\
{[0.80]}\end{array}$ & $\begin{array}{l}-0.78 \\
(0.70) \\
{[-1.35]}\end{array}$ & $\begin{array}{c}0.37 \\
(0.16)^{* *} \\
{[0.66]}\end{array}$ & $\begin{array}{c}0.23 \\
(0.18) \\
{[0.48]}\end{array}$ \\
\hline $\begin{array}{l}\text { Footloose } \\
\text { industries }\end{array}$ & $\begin{array}{c}0.81 \\
(0.25)^{* * *} \\
{[1.54]}\end{array}$ & $\begin{array}{c}-0.18 \\
(0.24) \\
{[-0.33]}\end{array}$ & $\begin{array}{c}-0.23 \\
(0.24) \\
{[-0.42]}\end{array}$ & $\begin{array}{l}-0.39 \\
(0.30) \\
{[-0.70]}\end{array}$ & $\begin{array}{c}0.06 \\
(0.25) \\
{[0.10]}\end{array}$ & $\begin{array}{c}0.15 \\
(0.25) \\
{[0.22]}\end{array}$ & $\begin{array}{c}0.19 \\
(0.18) \\
{[0.34]}\end{array}$ & $\begin{array}{c}0.10 \\
(0.24) \\
{[0.13]}\end{array}$ & $\begin{array}{c}0.57 \\
(0.48) \\
{[0.98]}\end{array}$ & $\begin{array}{c}0.47 \\
(0.15)^{* * *} \\
{[0.83]}\end{array}$ & $\begin{array}{c}0.13 \\
(0.17) \\
{[0.27]}\end{array}$ \\
\hline $\mathbf{N}$ & 144 & 288 & 288 & 288 & 336 & 192 & 576 & 288 & 96 & 672 & 309 \\
\hline
\end{tabular}

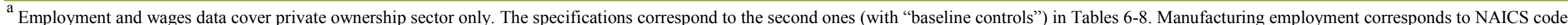
31-33, and footloose industries are information (51), finance and insurance (52), and professional and technical services (54).

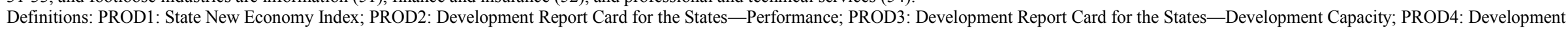

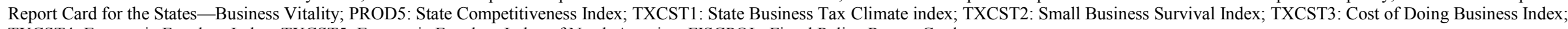
TXCST4: Economic Freedom Index; TXCST5: Economic Freedom Index of North America; FISCPOL: Fiscal Policy Report Card. 


\begin{tabular}{|c|c|c|}
\hline & Description / variables included & $\begin{array}{l}\text { Sub-index } \\
\text { weight }\end{array}$ \\
\hline \multicolumn{3}{|c|}{ A. State Business Tax Climate Index (TXCST1) } \\
\hline Corporate tax sub-index & $\begin{array}{l}\text { Tax rate sub-index: corporate income tax top rate; bracket structure; gross receipts rate } \\
\text { Tax base sub-index: availability of certain credits, deductions and exemptions; ability of taxpayers to } \\
\text { deduct net operating losses; smaller tax base issues (under gross receipts tax, the three tax base criteria } \\
\text { are replaced by availability of deductions from gross receipts for employee compensation costs and } \\
\text { cost of goods sold) }\end{array}$ & 19.4 \\
\hline $\begin{array}{l}\text { Individual income tax } \\
\text { sub-index }\end{array}$ & $\begin{array}{l}\text { Tax rate sub-index: top marginal tax rate and graduated rate structure (takes into account starting } \\
\text { points of top brackets, number of brackets, and average width of brackets) } \\
\text { Tax base sub-index: marriage penalty; capital gains taxation; double taxation of capital income; minor } \\
\text { base issues }\end{array}$ & 29.2 \\
\hline Sales tax sub-index & $\begin{array}{l}\text { Tax rate sub-index: state-level rate and combined state-local rate } \\
\text { Tax base sub-index: whether base includes variety of business-to-business transactions such as } \\
\text { agricultural products, services, machinery, computer software, and leased or rented items; whether } \\
\text { base includes goods and services typically purchased by consumers; excise tax rate on products such } \\
\text { as gasoline, diesel fuel, tobacco, spirits, and beer }\end{array}$ & 21.5 \\
\hline Property tax sub-index & $\begin{array}{l}\text { Tax rate sub-index: property tax collection, measured both per capita and as percentage of personal } \\
\text { income; capital stock tax rates and maximum payments } \\
\text { Tax base sub-index: whether levies wealth taxes such as inheritance, estate, gift, inventory, and } \\
\text { intangible property }\end{array}$ & 15.7 \\
\hline $\begin{array}{l}\text { Unemployment insurance } \\
\text { tax sub-index }\end{array}$ & $\begin{array}{l}\text { Tax rate sub-index: rates levied in the most recent year; statutory rate schedules that could be } \\
\text { implemented depending on the state of the economy and the UI fund } \\
\text { Tax base sub-index: experience rating formulas; charging methods; and smaller factors }\end{array}$ & 14.2 \\
\hline \multicolumn{3}{|c|}{ B. Economic Freedom Index of North America (TXCST5) } \\
\hline $\begin{array}{l}\text { Size of government sub- } \\
\text { index }\end{array}$ & $\begin{array}{l}\text { General consumption expenditures by government as a percent of GDP; transfers and subsidies as } \\
\text { percent of GDP; social security payments (includes unemployment insurance, disability, public } \\
\text { pensions) as percent of GDP }\end{array}$ & 33.3 \\
\hline $\begin{array}{l}\text { Labor market freedom } \\
\text { sub-index }\end{array}$ & $\begin{array}{l}\text { Minimum wage legislation; government employment as a percent of total state employment; union } \\
\text { density }\end{array}$ & 33.3 \\
\hline $\begin{array}{l}\text { Takings and } \\
\text { discriminatory taxation } \\
\text { sub-index }\end{array}$ & $\begin{array}{l}\text { Total tax revenue as percent of GDP; top marginal income tax rate and income threshold at which } \\
\text { applies; indirect tax revenue as a percent of GDP; sales taxes collected as a percent of GDP }\end{array}$ & 33.3 \\
\hline \multicolumn{3}{|c|}{ C. Economic Freedom Index (TXCST4) } \\
\hline Fiscal sub-index & $\begin{array}{l}\text { Average days required for work to cover taxes; per capita state tax revenue; per capita state and local } \\
\text { property tax revenue; tax burden on high income families; per capita state government death and gift } \\
\text { tax revenue; per capita state government severance tax revenue; personal income taxes; sales taxes; } \\
\text { excise taxes; license taxes; corporate taxes; state debt; tax exemptions }\end{array}$ & 34.9 \\
\hline Regulatory sub-index & $\begin{array}{l}\text { Licensing requirements for non-health professions; licensing requirements for health professions; } \\
\text { continuing education requirements for selected professions; percent land owned by federal } \\
\text { government; purchasing regulations; public school regulation; labor legislation; full-time-equivalent } \\
\text { employees of state public utilities commissions; corporate constituency statutes; property rights } \\
\text { legislation; strictness of state gun laws; state seat belt laws; state provisions for minimum age for } \\
\text { driver's licenses; full-time-equivalent employees of insurance regulation organization; state legislation } \\
\text { regarding environmental health }\end{array}$ & 34.2 \\
\hline $\begin{array}{l}\text { Welfare spending sub- } \\
\text { index }\end{array}$ & $\begin{array}{l}\text { Per capita state and local welfare spending; percent of population receiving public aid; Medicare } \\
\text { benefit payments per enrollee; per capita Medicaid spending; average monthly Food Stamp benefit per } \\
\text { recipient; monthly TANF benefit for family of three; average monthly benefit per participant for } \\
\text { Women, Infants, and Children Special Nutrition Program; commodity costs of National School Lunch } \\
\text { Program per participant }\end{array}$ & 37.3 \\
\hline $\begin{array}{l}\text { Government size sub- } \\
\text { index }\end{array}$ & $\begin{array}{l}\text { State and local total expenditures as a percent of GSP; size of government workforce; citizen } \\
\text { representation (avg. of total number of government units, and legislators per million people) }\end{array}$ & 6.3 \\
\hline Judicial & $\begin{array}{l}\text { Number of resident active attorneys; Attorney General salary; judges' compensation; judges' terms; } \\
\text { judges' selection method; state has Illinois Brick Repealer statutes (which restrict anti-trust suits); tort } \\
\text { reform; medical-liability reform }\end{array}$ & -12.6 \\
\hline
\end{tabular}

\footnotetext{
${ }^{a}$ State Business Tax Climate sub-index weights described are for 2006 and 2007; sub-index weighting was different for 2003 and 2004. For the Economic Freedom Index, sub-index weights described are for 2004; sub-index weighting was different in 1999. Note that variables in some sub-indexes are described relative to state GSP, and others relative to GDP; these are interchangeable terms. Small Business Tax Climate sub-indexes are weighted in direct proportion with how much each subindex varies across states. The Economic Freedom Index sub-indexes are weighted according to a principal components analysis, and the negative weight on the judicial sub-index presumably reflects a weak or negative correlation with other Economic Freedom Index sub-indexes.
} 
TABLE 11: Regressions Including All Sub-Indexes within an Index, 1992-2008 ${ }^{\mathrm{a}}$

\begin{tabular}{|c|c|c|c|c|}
\hline & $\begin{array}{c}\text { QCEW } \\
\text { Employment }\end{array}$ & $\begin{array}{l}\text { QCEW Total } \\
\text { Wages }\end{array}$ & GSP & $\begin{array}{l}\text { Employment change } \\
\text { due to births }\end{array}$ \\
\hline \multicolumn{5}{|c|}{ A. State Business Tax Climate Index (TXCST1) } \\
\hline $\begin{array}{l}\text { Corporate tax } \\
\text { sub-index }\end{array}$ & $\begin{array}{c}0.21 \\
(0.13) \\
{[0.22]}\end{array}$ & $\begin{array}{c}0.47 \\
(0.21)^{* *} \\
{[0.49]}\end{array}$ & $\begin{array}{c}0.51 \\
(0.23)^{* *} \\
{[0.53]}\end{array}$ & $\begin{array}{c}0.07 \\
(0.10) \\
{[0.08]}\end{array}$ \\
\hline & 0.08 & -0.03 & -0.09 & 0.11 \\
\hline \multirow{2}{*}{ tax sub-index } & $(0.14)$ & $(0.20)$ & $(0.25)$ & $(0.10)$ \\
\hline & [0.10] & {$[-0.04]$} & {$[-0.11]$} & {$[0.14]$} \\
\hline \multirow[t]{3}{*}{ Sales tax sub-index } & 0.01 & -0.10 & -0.34 & 0.09 \\
\hline & $(0.08)$ & $(0.10)$ & $(0.15)^{* *}$ & $(0.07)$ \\
\hline & [0.01] & [-0.09] & {$[-0.30]$} & [0.08] \\
\hline \multirow[t]{3}{*}{ Property tax sub-index } & 0.13 & 0.05 & 0.34 & 0.01 \\
\hline & $(0.09)$ & $(0.14)$ & $(0.19)^{*}$ & $(0.08)$ \\
\hline & [0.23] & [0.08] & {$[0.60]$} & [0.02] \\
\hline Unemployment & 0.05 & 0.07 & 0.13 & -0.05 \\
\hline \multirow{2}{*}{ Insurance tax sub-index } & $(0.07)$ & $(0.12)$ & $(0.15)$ & $(0.08)$ \\
\hline & [0.09] & {$[0.13]$} & [0.24] & {$[-0.09]$} \\
\hline $\mathrm{N}$ & 192 & 192 & 192 & 96 \\
\hline $\mathrm{R}^{2}$ & 0.50 & 0.49 & 0.44 & 0.59 \\
\hline Sub-index coefficients equal ( $p$-value) & 0.03 & 0.02 & 0.00 & 0.35 \\
\hline \multicolumn{5}{|c|}{ B. Economic Freedom Index of North America (TXCST5) } \\
\hline Size of & 0.36 & 0.47 & 0.15 & 0.22 \\
\hline \multirow[t]{2}{*}{ government sub-index } & $(0.12)^{* * *}$ & $(0.15)^{* * *}$ & $(0.15)$ & $(0.10)^{* *}$ \\
\hline & [0.63] & [0.83] & {$[0.26]$} & [0.38] \\
\hline Labor market & 0.002 & 0.12 & 0.22 & -0.001 \\
\hline \multirow[t]{2}{*}{ freedom sub-index } & $(0.12)$ & $(0.14)$ & $(0.16)$ & $(0.10)$ \\
\hline & {$[0.003]$} & {$[0.17]$} & {$[0.32]$} & {$[-0.00]$} \\
\hline Takings and & -0.13 & -0.15 & -0.06 & -0.06 \\
\hline discriminatory taxation & $(0.12)$ & $(0.14)$ & $(0.13)$ & $(0.10)$ \\
\hline sub-index & {$[-0.22]$} & {$[-0.26]$} & {$[-0.11]$} & {$[-0.10]$} \\
\hline $\mathrm{N}$ & 672 & 672 & 432 & 672 \\
\hline $\mathrm{R}^{2}$ & 0.68 & 0.61 & 0.29 & 0.79 \\
\hline Sub-index coefficients equal ( $p$-value) & 0.02 & 0.00 & 0.15 & 0.08 \\
\hline \multicolumn{5}{|l|}{ C. Economic Freedom Index (TXCST4) } \\
\hline \multirow{3}{*}{ Fiscal sub-index } & 0.07 & -0.02 & -0.24 & -0.08 \\
\hline & $(0.17)$ & $(0.25)$ & $(0.28)$ & $(0.10)$ \\
\hline & [0.13] & {$[-0.04]$} & {$[-0.42]$} & {$[-0.13]$} \\
\hline \multirow[t]{3}{*}{ Regulatory sub-index } & -0.16 & -0.15 & -0.07 & 0.04 \\
\hline & $(0.12)$ & $(0.20)$ & $(0.29)$ & $(0.10)$ \\
\hline & {$[-0.25]$} & {$[-0.23]$} & [-0.12] & {$[0.06]$} \\
\hline Welfare spending & 0.31 & 0.37 & 0.53 & 0.30 \\
\hline \multirow[t]{2}{*}{ sub-index } & $(0.15)^{* *}$ & $(0.23)$ & $(0.28)^{*}$ & $(0.14)^{* *}$ \\
\hline & {$[0.46]$} & [0.54] & {$[0.79]$} & [0.44] \\
\hline Government size & 0.10 & 0.33 & 0.10 & 0.16 \\
\hline \multirow[t]{2}{*}{ sub-index } & $(0.10)$ & $(0.20)$ & $(0.19)$ & $(0.08)^{*}$ \\
\hline & [0.17] & [0.54] & [0.16] & {$[0.26]$} \\
\hline \multirow[t]{3}{*}{ Judicial sub-index } & -0.11 & -0.08 & -0.12 & 0.11 \\
\hline & $(0.11)$ & $(0.23)$ & $(0.26)$ & $(0.08)$ \\
\hline & {$[-0.21]$} & {$[-0.16]$} & {$[-0.23]$} & {$[0.21]$} \\
\hline $\mathrm{N}$ & 96 & 96 & 96 & 96 \\
\hline $\mathrm{R}^{2}$ & 0.43 & 0.52 & 0.38 & 0.78 \\
\hline Sub-index coefficients equal ( $p$-value) & 0.02 & 0.12 & 0.40 & 0.02 \\
\hline
\end{tabular}

${ }^{\mathrm{a}}$ The dependent variable is 1 -year changes of the variable in the first column, and all controls are included, so the specifications correspond to the second ones in Tables 6-8. The sub-indexes are scaled so that positive values are intended to reflect a "better" business climate; e.g., higher values of the sub-indexes correspond to lower taxes or lower welfare and transfer payments. 
FIGURE 1: Contributions of Business Climate Index and Control Variables to Employment Growth (QCEW), 1992-2008. ${ }^{\text {a }}$

${ }^{a}$ Presents product of coefficients from Table 6 and states' values for business climate index and control variables relative to mean. Units are percentage points of annual employment growth. Estimates are averaged over values from TXCST1, TXCST4, and TXCST5 models. 


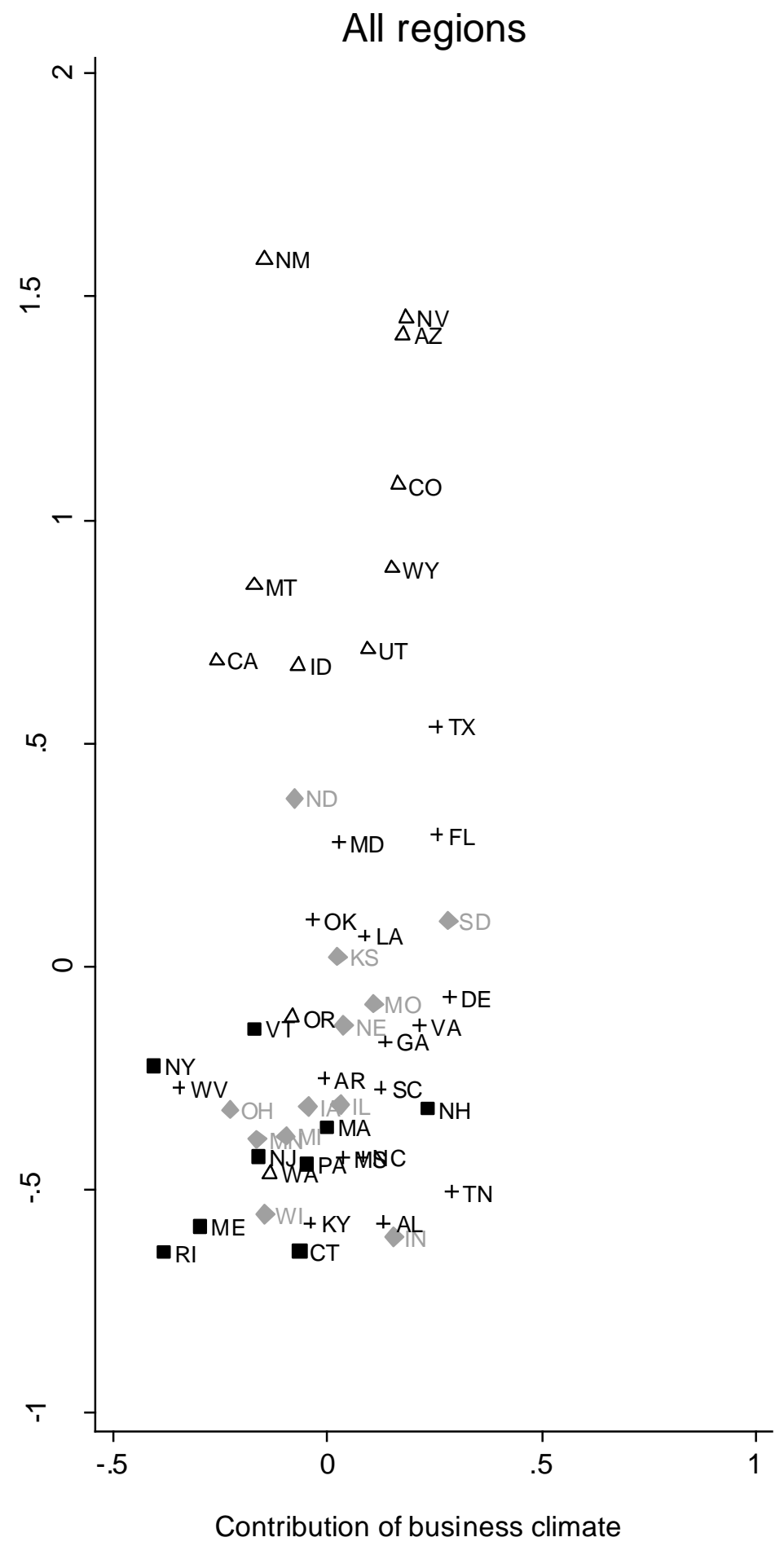

- Northeast Midwest + South $\Delta$ West 